University of South Carolina

Scholar Commons

2015

Cloning Miranda: Why Medical Miranda Supports the PreAssertion of Criminal Miranda Rights

Colin Miller

University of South Carolina - Columbia, mille933@law.sc.edu

Follow this and additional works at: https://scholarcommons.sc.edu/law_facpub

Part of the Law Commons

Recommended Citation

Colin Miller, Cloning Miranda: Why Medical Miranda Supports the Pre-Assertion of Criminal Miranda Rights, 2015 WIS. L. REV. 863 (2015).

This Article is brought to you by the Law School at Scholar Commons. It has been accepted for inclusion in Faculty Publications by an authorized administrator of Scholar Commons. For more information, please contact digres@mailbox.sc.edu. 


\title{
CLONING MIRANDA: WHY MEDICAL MIRANDA SUPPORTS THE PRE-ASSERTION OF CRIMINAL MIRANDA RIGHTS
}

\author{
COLIN MILLER*
}

\begin{abstract}
Courts across the country have concluded that suspects cannot assert their Miranda rights before being subjected to custodial interrogation. This reluctance to credit pre-assertions can be traced to dicta from McNeil v. Wisconsin, in which the Supreme Court noted that "[m]ost rights must be asserted when the government seeks to take the action they protect against." This Article challenges this notion by drawing an analogy between criminal suspects and patients. In 1990, Congress passed the Patient Self-Determination Act ("PSDA"), the so-called "medical Miranda," which requires health care providers who accept money from Medicaid or Medicare to inform patients of their rights regarding advance directives and the refusal of medical treatment prior to admission.

The goal of the PSDA is to inform patients of their health care rights prior to admission so that they can assert those rights before being pressed into an unfamiliar environment in which they face possible isolation and coercion. This Article contends that the same principles that led to the passage of the PSDA support the ability of suspects to be able to pre-assert their Miranda rights when custodial interrogation is "imminent." It also sets up a framework for determining whether a suspect properly pre-asserted his Miranda rights.
\end{abstract}

Introduction

I. Miranda and Its Progeny ..................................... 866

A. Miranda and Fifth Amendment Rights ....................866

B. Michigan v. Mosley and the Right to Remain Silent........867

C. Edwards v. Arizona and the Edwards Prophylaxis ..........869

D. Pre-Assertion of Miranda Rights .......................8 870

1. McNeil v. Wisconsin and the Dicta on Pre-Assertion ..870

2. McNeil's Aftermath and the Adoption of the

Pre-Assertion Dicta..................................8 873

II. The Patient Self-Determination Act...........................8 875

A. Cruzan and the Right to Refuse Unwanted

Medical Treatment.................................. 875

B. The Patient Self-Determination Act..................... 876

1. Introduction..................................... 876

2. Goals of the PSDA ............................... 877

a. Pre-Asserting Rights Before Isolation .............8 877

* Associate Dean for Faculty Development and Professor, University of South Carolina School of Law; Blog Editor, EvidenceProf Blog, http://lawprofessors.typepad.com/evidenceprof/. 
b. Overcoming the Secrecy of the Physician-Patient Relationship ...................878

c. Counteracting the Unfamiliarity of

Health Care Facilities ..............................8879

d. Preventing Coercion ...............................879

e. Promoting Autonomy ............................ 880

3. Medical Miranda ................................... 881

III. Miranda Revisited ......................................... 882

A. Introduction ..................................... 882

B. The Similar Justifications for Criminal and

Medical Miranda ....................................883

1. Asserting Rights Before Isolation ....................883

2. Overcoming the Secrecy of the

Police Officer-Suspect Relationship .................884

3. Counteracting the Unfamiliarity of the Stationhouse ...885

4. Preventing Coercion .................................. 886

5. Promoting Free Choice/Autonomy ....................887

6. The Ineffectiveness of Miranda ......................888

7. Pre-Assertion of Rights Before Governmental Action .889

C. Applying the Existing Miranda Framework to Allow for Pre-Assertion........................................8 891

1. Invocation of Miranda Rights When Interrogation

Is "Imminent" ...................................... 891

2. The Ability of Officers to Pre-Administer the

Miranda Warning......................................886

D. The Limited Duration of Miranda Rights ................. 901

E. The Edwards Prophylaxis Should Be Extended to

Cover Pre-Assertions .................................... 902

Conclusion................................................ 905

\section{INTRODUCTION}

Demetrius Wilson was a suspect in the fatal shooting of Reginald Knox, and Detective Brian Krueger "put out word" that he wanted to interview Wilson. ${ }^{1}$ Wilson's stepfather contacted Krueger and arranged for Wilson to come to the police station with relatives for an interview. ${ }^{2}$ While being interviewed at the police station, Wilson made a first statement in which he claimed he shot Knox because Knox was robbing him at gunpoint. ${ }^{3}$ Police officers then accompanied Wilson and his

1. Wilson v. Commonwealth, 199 S.W.3d 175, 177 (Ky. 2006).

2. Id.

3. $I d$. 
relatives to the crime scene, where Wilson walked them through his version of events. ${ }^{4}$ The officers (1) responded that his story was not consistent with the evidence; and (2) lied to him by telling him that video cameras recorded the shooting. ${ }^{5}$ The officers suggested that Wilson and his relatives talk things over at lunch and return to the police station in the afternoon. ${ }^{6}$

Upon returning to the police station, Wilson's stepfather told Detective Krueger that the family consulted with a lawyer, who told Wilson not to speak to police. ${ }^{7}$ Wilson then told a police officer "that if the police wished to speak with him, they should contact his attorney." 8 Upon these words leaving Wilson's lips, he was immediately arrested and taken to an interview room. ${ }^{9}$ There, Wilson was read his Miranda rights, said he understood them, and gave an incriminatory statement that was inconsistent with his first statement. ${ }^{10}$

The court denied Wilson's motion to suppress his second statement, and he was eventually convicted of murder. ${ }^{11}$ Wilson appealed, claiming he validly invoked his Miranda rights prior to giving his second statement, meaning the statement was inadmissible under the Miranda right to counsel. ${ }^{12}$ The Supreme Court of Kentucky agreed that the second statement would be inadmissible if Wilson properly invoked his Miranda rights; ${ }^{13}$ however, the court concluded that Wilson's Miranda right to counsel had not yet attached because his request for an attorney was made before he was subjected to custodial interrogation. ${ }^{14}$ As support, the court cited the following dicta from the Supreme Court's opinion in McNeil v. Wisconsin ${ }^{15}$ :

We have in fact never held that a person can invoke his Miranda rights anticipatorily, in a context other than "custodial interrogation" . . . . Most rights must be asserted when the government seeks to take the action they protect against. The fact that we have allowed the Miranda right to counsel, once asserted, to be effective with respect to future

$\begin{array}{ll}\text { 4. } & I d . \\ 5 . & I d . \\ 6 . & I d . \\ 7 . & I d . \\ 8 . & I d . \\ 9 . & I d . \\ 10 . & I d . \\ 11 . & I d . \text { at } 176 . \\ 12 . & I d . \text { at } 178 . \\ 13 . & I d . \\ 14 . & I d . \\ 15 . & 501 \text { U.S. } 171(1991) .\end{array}$


custodial interrogation does not necessarily mean that we will allow it to be asserted initially outside the context of custodial interrogation, with similar future effect. ${ }^{16}$

The court thereafter laid out a laundry list of other court opinions from around the country, each of which also cited this dicta from McNeil to conclude that a suspect cannot invoke Miranda "rights unless he or she is subject to custodial interrogation." 17

The thesis of this Article is that, contrary to the conventional wisdom, suspects should be able to pre-assert their Miranda rights. This Article advances this thesis by reference to the Patient Self-Determination Act ("PSDA"), the so-called "medical Miranda," which requires all health care providers who accept money from Medicaid or Medicare to inform patients of their rights regarding advance directives and the refusal of medical treatment prior to admission in health care facilities. Specifically, this Article contends that the same policy goals that allow and even encourage patients to pre-assert their medical Miranda rights militate in favor of recognizing pre-assertion of criminal Miranda rights. Moreover, this Article argues that courts should determine whether custodial interrogation is "imminent" and thus conducive to pre-assertion of Miranda rights by applying the same "totality of the circumstances" test they use to decide whether police officers can pre-administer the Miranda warning.

Section I looks at the Miranda opinion and the subsequent Supreme Court opinions expanding and narrowing its scope. Section II analyzes the PSDA and the reasons why Congress thought it made sense to inform patients of the ability to execute advance directives before being admitted into health care facilities. Finally, Section III argues that the same principles that led to the passage of the PSDA support the ability of suspects to be able to pre-assert their Miranda rights when custodial interrogation is "imminent." The Article concludes by setting up a framework for determining whether a suspect properly pre-asserted his Miranda rights.

\section{MIRANDA AND ITS PROGENY}

\section{A. Miranda and Fifth Amendment Rights}

The Supreme Court's 1966 opinion in Miranda v. Arizona ${ }^{18}$ resolved four consolidated cases. ${ }^{19}$ In all four cases, police officers

16. Wilson, 199 S.W.3d at 178-79 (quoting McNeil, 501 U.S. at 182 n.3).

17. Id. at 179 .

18. 384 U.S. 436 (1966). 
interrogated suspects without first informing them of their right to remain silent and their right to counsel. ${ }^{20}$ The four suspects each claimed that their interrogations violated the Fifth Amendment's requirement that "[n]o person . . . shall be compelled in any criminal case to be a witness against himself . . .."21

The Supreme Court agreed, concluding that "the prosecution may not use statements, whether exculpatory or inculpatory, stemming from custodial interrogation of the defendant unless it demonstrates the use of procedural safeguards effective to secure the privilege against self-incrimination." 22 The Court then defined "custodial interrogation" as "questioning initiated by law enforcement officers after a person has been taken into custody or otherwise deprived of his freedom of action in any significant way." ${ }^{23}$ According to the Court, before subjecting a suspect to such custodial interrogation, law enforcement officers must adhere to the following procedural safeguard or its functional equivalent: "the person must be warned that he has a right to remain silent, that any statement he does make may be used as evidence against him, and that he has a right to the presence of an attorney, either retained or appointed." 24

In response to this Miranda warning, the suspect can voluntarily, knowingly, and intelligently waive these rights. ${ }^{25}$ If, however, the suspect indicates that he wishes to speak with an attorney, the interrogation cannot proceed. ${ }^{26}$ Moreover, if the suspect is alone and invokes his right to remain silent by stating that he does not wish to be interrogated, the officers cannot question him. ${ }^{27}$

\section{B. Michigan v. Mosley and the Right to Remain Silent}

Nine years later, in 1975, the Supreme Court was confronted with the question of whether law enforcement officers can re-administer the Miranda warning and interrogate a suspect who has already invoked his

19. Id. at $491-98$.

20. See id. One of these suspects, Ernesto Miranda, was charged with kidnapping, rape, and armed robbery. Two police officers put Miranda in an interrogation room and emerged with a written confession two hours later without any indication they had informed him of his constitutional rights. See id. at 491-92.

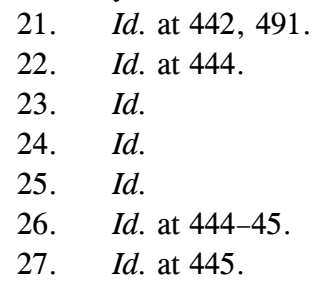


right to remain silent. In Michigan v. Mosley, ${ }^{28}$ Detective James Cowie arrested Richard Mosley in connection with a string of robberies and read him the Miranda warning. ${ }^{29}$ After Cowie began interrogating him, Mosley stated that he did not want to answer any questions about the robberies. ${ }^{30}$ Cowie ceased questioning Mosley and took him to the cell block. ${ }^{31}$

Over two hours later, a different detective took Mosley to the Homicide Bureau and read him the Miranda warning. ${ }^{32}$ Mosley indicated that he understood the warning, and the detective proceeded to question him about a murder. ${ }^{33}$ After first denying his involvement, Mosley incriminated himself in the homicide. ${ }^{34}$ Upon being charged with first-degree murder, Mosley moved to suppress his confession, but the trial court denied the motion. ${ }^{35}$ Following his ensuing conviction, Mosley appealed, claiming that the admission of his confession violated the Miranda doctrine. ${ }^{36}$

The Supreme Court noted "that the admissibility of statements obtained after the person in custody has decided to remain silent depends under Miranda on whether his 'right to cut off questioning' was 'scrupulously honored." 37 Applying this standard, the Court concluded that Mosley's right to cut off questioning was, in fact scrupulously honored. ${ }^{38}$ According to the Court, after Mosley initially asserted his right to remain silent, "the police here immediately ceased the interrogation, resumed questioning only after the passage of a significant period of time and the provision of a fresh set of warnings, and restricted the second interrogation to a crime that had not been a subject of the earlier interrogation." 39

\footnotetext{
28. 423 U.S. 96 (1975).

29. Id. at 97 .

30. Id.

31. Id.

32. Id. at $97-98$.

33. Id. at 98 .

34. Id.

35. Id. at $98-99$.

36. Id. at 99 .

37. Id. at 104 (quoting Miranda v. Arizona, 384 U.S. 436, 474, 479 (1966)).

38. Id.

39. Id. at 106. Many courts have referred to these four factors as the Mosley factors. See, e.g., State v. Hartwig, 366 N.W.2d 866, 870 (Wis. 1985). These factors, however, are not to be "woodenly applied," and none of them alone is dispositive on the issue of whether a suspect's right to remain silent was scrupulously honored. Id.; see, e.g., Grant v. Warden, Maine State Prison, 616 F.3d 72, 77 (1st Cir. 2010).
} 


\section{Edwards v. Arizona and the Edwards Prophylaxis}

Another six years later, the Supreme Court was confronted with a similar question: can law enforcement officers re-administer the Miranda warning and interrogate a suspect who has already invoked his Miranda right to counsel? This time, however, the result was very different. In Edwards v. Arizona,${ }^{40}$ Robert Edwards was charged with robbery, burglary, and first-degree murder. ${ }^{41}$ During custodial interrogation and after being read the Miranda warning, Edwards expressed interest in making a deal, prompting the interrogating officer to give him the county attorney's phone number. ${ }^{42}$ Edwards dialed the number before quickly hanging up and saying, "I want an attorney before making a deal." ${ }^{43}$ The officer responded by taking Edwards to the county jail. ${ }^{44}$

The next morning, a guard informed Edwards that two detectives wished to speak to him, prompting Edwards to respond that he did not want to talk with anyone. ${ }^{45}$ The guard responded that Edwards had to talk to the detectives. ${ }^{46}$ Edwards thereafter met with the detectives, who read him the Miranda warning and played him the taped statement of an alleged accomplice who had implicated him. ${ }^{47}$ Edwards then agreed to speak and incriminated himself. ${ }^{48}$ Edwards moved to suppress his confession, but the trial court denied the motion, concluding that his statement was voluntary. ${ }^{49}$

The United States Supreme Court reversed, concluding "that when an accused has invoked his right to have counsel present during custodial interrogation, a valid waiver of that right cannot be established by showing only that he responded to further police-initiated custodial interrogation even if he has been advised of his rights." ${ }^{50}$ The Court further found that a suspect who has "expressed his desire to deal with the police only through counsel, is not subject to further interrogation by the authorities until counsel has been made available to

$\begin{array}{ll}\text { 40. } & \text { 451 U.S. } 477(1981) . \\ \text { 41. } & \text { Id. } \text { at } 478 . \\ 42 . & I d . \text { at } 478-79 . \\ 43 . & I d . \text { at } 479 . \\ 44 . & I d . \\ 45 . & I d . \\ 46 . & I d . \\ 47 . & I d . \\ 48 . & I d . \\ 49 . & I d . \text { at } 479-80 . \\ 50 . & I d . \text { at } 484 .\end{array}$


him, unless the accused himself initiates further communication, exchanges, or conversations with the police." ${ }^{51}$

The Supreme Court has subsequently referred to this holding as the "Edwards prophylaxis" because it is a judicially crafted, non-constitutional rule rather than one that is constitutionally required. ${ }^{52}$ In other words, this prophylaxis is merely a "rule established to protect the Fifth Amendment based Miranda right to . . . counsel" and not part of the Miranda right itself. ${ }^{53}$ Under this prophylaxis, the defendant's subsequent waiver of his right to counsel is presumed to be involuntary and the result of the inherently compelling pressures of custodial interrogation. ${ }^{54}$ Because this presumption is merely a prophylaxis, either the Supreme Court or a lower court can decide to expand it to different factual contexts. ${ }^{55}$ That said, because the Edwards rule is prophylactic, a court can extend it to cover additional situations only after balancing benefits against costs and determining whether the extension serves its prophylactic purpose. ${ }^{56}$

\section{Pre-Assertion of Miranda Rights}

\section{MCNEIL $V$. WISCONSIN AND THE DICTA ON PRE-ASSERTION}

A decade later, in McNeil v. Wisconsin, the defendant asked the Supreme Court to extend the Edwards prophylaxis. In McNeil, Paul McNeil was arrested on suspicion of armed robbery. ${ }^{57}$ When two Milwaukee County deputy sheriffs read McNeil the Miranda warning and sought to interrogate him, he refused to answer any questions but did not ask for an attorney. ${ }^{58}$ At his initial appearance/bail hearing, McNeil requested and was appointed a public defender. ${ }^{59}$ After his bail hearing, McNeil was incarcerated, and Detective Joseph Butts visited him on three occasions over the next four days to talk about a murder,

51. Id. at 484-85.

52. See, e.g., Maryland v. Shatzer, 559 U.S. 98, 116 (2010) (citing the "Edwards prophylaxis").

53. Montejo v. Louisiana, 556 U.S. 778, 787 (2009).

54. Shatzer, 559 U.S. at 115-16.

55. See, e.g., State v. Stewart, 780 P.2d 844, 850 (Wash. 1989) (en banc) ("Stewart requests this court to extend the Edwards prophylactic rule in order to shield his custodial confession that occurred following the invocation of his Sixth Amendment right to counsel at an arraignment on an unrelated charge.").

56. Shatzer, 559 U.S. at 106-09.

57. McNeil v. Wisconsin, 501 U.S. 171, 173 (1991).

58. Id.

59. Id. 
an attempted murder, and an armed burglary in Caledonia. ${ }^{60}$ Each time, Butts read McNeil the Miranda warning, and, each time, McNeil signed a Miranda waiver. ${ }^{61}$ During Butts' third visit, McNeil made an incriminatory statement while Butts interrogated him. ${ }^{62}$

The next day, McNeil was charged with the Caledonia crimes. ${ }^{63}$ He moved to suppress his confession, but the trial court denied the motion. ${ }^{64}$ After being convicted, McNeil appealed, claiming that his courtroom appearance with counsel constituted invocation of his Miranda right to counsel. ${ }^{65}$

The Supreme Court began its analysis by considering the right to counsel contained in the Sixth Amendment, which states in relevant part that "[i]n all criminal prosecutions, the accused shall enjoy the right ... to have the Assistance of Counsel for his defence."66 The Court noted that this Sixth Amendment right to counsel is offense-specific and only attaches when a prosecution is commenced via a "formal charge, preliminary hearing, indictment, information, or arraignment." 67 Therefore, McNeil's Sixth Amendment right to counsel had only attached in connection with the armed robbery and had not yet attached in connection with the Caledonia crimes. ${ }^{68}$

McNeil, however, claimed that his invocation of his Sixth Amendment right to counsel in connection with the armed robbery charge also constituted "an invocation of the non-offense-specific Miranda-Edwards right." 69 The Court agreed that the Miranda right to counsel "is not offense specific: Once a suspect invokes the Miranda right to counsel for interrogation regarding one offense, he may not be reapproached regarding any offense unless counsel is present."70 The Court, however, disagreed with the argument that invocation of the Sixth Amendment right to counsel implies invocation of the Miranda/Fifth Amendment right to counsel; instead, it concluded that "[o]ne might be quite willing to speak to the police without counsel present concerning many matters, but not the matter under prosecution." ${ }^{71}$ Moreover, the Court admonished that invocation of the

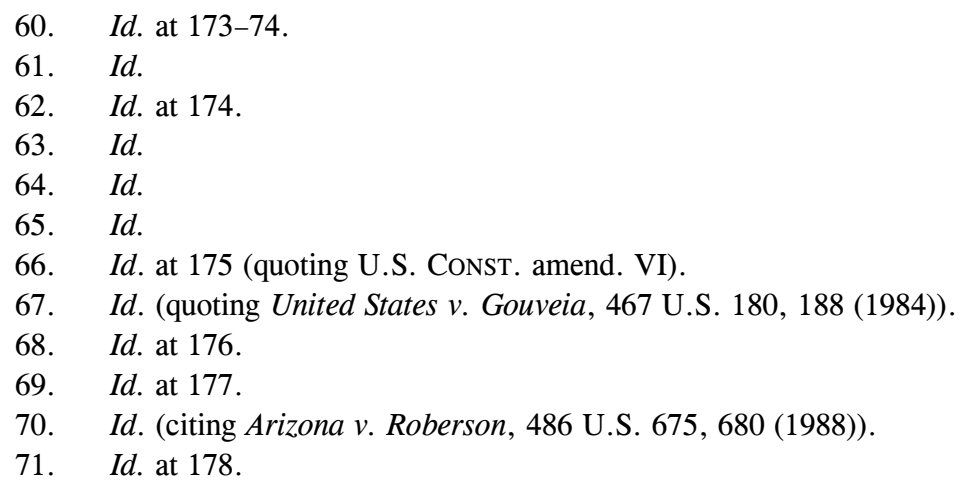


Miranda right to counsel "requires, at a minimum, some statement that can reasonably be construed to be an expression of a desire for the assistance of an attorney in dealing with custodial interrogation by the police. Requesting the assistance of an attorney at a bail hearing does not bear that construction." 72

McNeil nonetheless contended that the Court should still find attachment of the Sixth Amendment right to counsel implied invocation of the Miranda right to counsel as a matter of sound policy. ${ }^{73}$ In other words, McNeil asked the Court to extend the Edwards prophylaxis. ${ }^{74}$ The Court refused, finding that "if we were to adopt petitioner's rule, most persons in pretrial custody for serious offenses would be unapproachable by police officers suspecting them of involvement in other crimes, even though they have never expressed any unwillingness to be questioned." 75

After rejecting this argument, the McNeil majority addressed the dissent in a footnote that was partially quoted in the introduction to this Article:

The dissent predicts that the result in this case will routinely be circumvented when, "[i]n future preliminary hearings, competent counsel . . . make sure that they, or their clients, make a statement on the record" invoking the Miranda right to counsel. We have in fact never held that a person can invoke his Miranda rights anticipatorily, in a context other than "custodial interrogation"-which a preliminary hearing will not always, or even usually, involve. If the Miranda right to counsel can be invoked at a preliminary hearing, it could be argued, there is no logical reason why it could not be invoked by a letter prior to arrest, or indeed even prior to identification as a suspect. Most rights must be asserted when the government seeks to take the action they protect against. The fact that we have allowed the Miranda right to counsel, once asserted, to be effective with respect to future custodial interrogation does not necessarily mean that we will allow it to be asserted initially outside the context of custodial interrogation, with similar future effect. Assuming, however, that an assertion at arraignment would be effective, and would be routinely made, the mere fact that adherence to the principle of our decisions will not have substantial
72. $I d$.
73. Id. at 180 .
74. Id. at 181.
75. Id. at $181-82$. 
consequences is no reason to abandon that principle. It would remain intolerable that a person in custody who had expressed no objection to being questioned would be unapproachable. ${ }^{76}$

\section{MCNEIL'S AFTERMATH AND THE ADOPTION OF THE PRE-ASSERTION DICTA}

In the aftermath of McNeil, courts across the country correctly concluded that this footnote was dicta. ${ }^{77}$ In $M c N e i l$, the Court determined that McNeil did not make any statement during his bail hearing that could "reasonably be construed to be an expression of a desire for the assistance of an attorney in dealing with custodial interrogation by the police."78 Therefore, the McNeil majority's speculation about whether a suspect can assert his Miranda rights anticipatorily and in a context other than custodial interrogation was unnecessary to its opinion. ${ }^{79}$

That said, while courts have construed this footnote as dicta, they have also categorically applied it to invalidate pre-assertions of Miranda rights. For instance, in State $v$. Relford ${ }^{80}$ police officers believed that Charles Relford committed a homicide and interrogated him after reading him the Miranda warning. ${ }^{81}$ At the end of this interrogation, the officers arrested Relford and transported him to jail. ${ }^{82}$ The following day, a sergeant told Relford about telephone restrictions at the jail and asked him if he wanted to speak to a lawyer. ${ }^{83}$ Relford answered that "he needed the public defender." 84 The sergeant responded that "a public defender would have to be appointed to him by the Court, however, if he wanted to call them, there was the phone, and I would provide the phone number for him." 85 Relford did not follow up on his request, but the police did follow up with Relford the next day, securing his confession after reading him the Miranda warning. ${ }^{86}$

76. Id. at $182 \mathrm{n} .3$ (alteration in original) (citations omitted) (quoting $i d$. at 184 (Stevens, J., dissenting)).

77. See, e.g., Alston v. Redman, 34 F.3d 1237, 1246 (3d Cir. 1994).

78. McNeil, 501 U.S. at 178.

79. Redman, 34 F.3d at 1246 ("[T]his passage in McNeil is essentially dicta, being a response to a hypothetical posed by the dissent . . . .").

80. 623 N.W.2d 343, 344 (Neb. Ct. App. 2001).

81. Id. at 344-45.

82. IId at 344 .

83. Id. at 345 .

84. Id.

85. Id.

86. Id. at 344-45. 
Relford was later charged with murder and moved to suppress his confession. ${ }^{87}$ The district court agreed with Relford, finding that his statement that "he needed the public defender" was an unequivocal and unambiguous invocation of his Miranda right to counsel. ${ }^{88}$ But the Court of Appeals of Nebraska reversed, citing the aforementioned footnote from $\mathrm{McNeil}^{89}$

The Nebraska court was not alone in citing McNeil; it noted that "[m]any state courts which have considered the issue have relied on the language in McNeil v. Wisconsin, to hold that one cannot anticipatorily invoke the Miranda right to counsel prior to custodial interrogation." 90 Moreover, "relying on McNeil v. Wisconsin, an overwhelming number of federal courts have also held that a defendant cannot invoke his Miranda rights outside the context of custodial interrogation." 91

While McNeil only involved the alleged assertion of the Miranda right to counsel, courts have also used it to defeat claims by suspects that they asserted their right to remain silent prior to custodial interrogation. For example, in Barnett $v$. State, ${ }^{92}$ Dustin Barnett voluntarily went to the police station where Detective Curtis Lampert took him to an interrogation room before telling him that he did not have to talk with police and that he was free to leave..$^{93}$ Barnett responded that he wanted to leave and did not want to talk. ${ }^{94}$ Detective Lampert responded by leaving the room, returning a few minutes later, and telling Barnett that he was no longer free to leave. ${ }^{95}$ Lampert later read Barnett the Miranda warning and interrogated him, resulting in Barnett making a number of incriminatory statements. ${ }^{96}$

After he was charged with first-degree murder with a deadly weapon and robbery with a deadly weapon, Barnett unsuccessfully moved to suppress his statements and was convicted. ${ }^{97}$ On appeal, the Supreme Court of Nevada cited McNeil for the proposition that Miranda rights cannot be asserted anticipatorily. ${ }^{98}$ Therefore, the court found no constitutional violation because "Barnett's initial invocation of

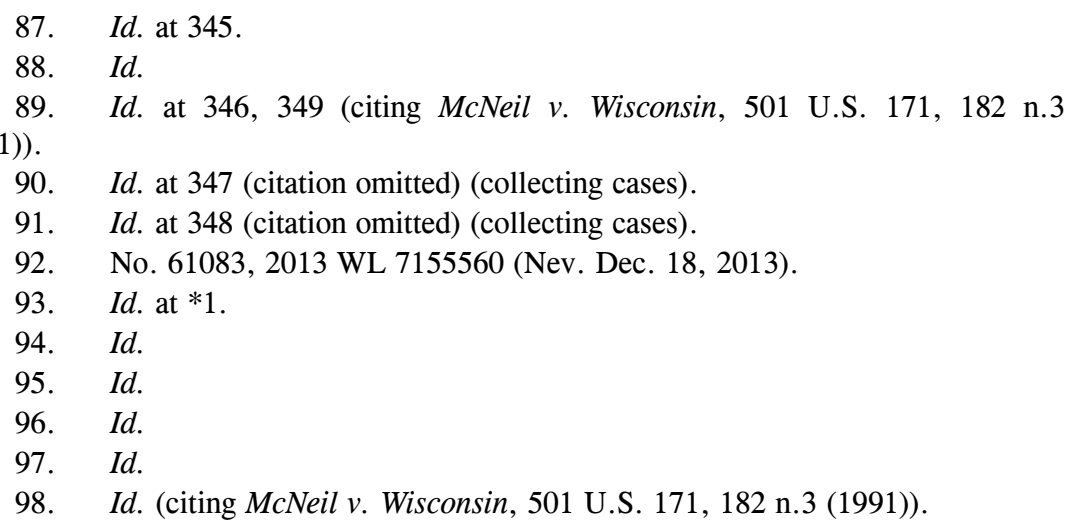


his right to remain silent occurred before Miranda circumstances even existed." 99

\section{The PATIENT SELF-Determination ACT}

\section{A. Cruzan and the Right to Refuse Unwanted Medical Treatment}

In Cruzan v. Director, Missouri Department of Health, ${ }^{100}$ Nancy Cruzan was rendered incompetent and dependent on life support as the result of an automobile accident. ${ }^{101}$ Thereafter, her parents and coguardians moved for "a court order directing the withdrawal of their daughter's artificial feeding and hydration equipment after it became apparent that she had virtually no chance of recovering her cognitive faculties." ${ }^{102}$ The Supreme Court of Missouri denied their request, concluding that they failed to prove by clear and convincing evidence that Cruzan would have wanted life support withdrawn under the present circumstances. ${ }^{103}$

In addressing this issue on appeal in June 1990, the United States Supreme Court concluded that "the common-law doctrine of informed consent is viewed as generally encompassing the right of a competent individual to refuse medical treatment." ${ }^{104}$ The Court was able to infer this "constitutionally protected liberty interest in refusing unwanted medical treatment" by considering both the Fourteenth Amendment's Due Process Clause and prior precedent regarding the right to bodily integrity. ${ }^{105}$ That said, the Court found no problem with Missouri enacting a procedural safeguard that surrogates seeking to withdraw life support must prove by clear and convincing evidence that the incompetent patient would have made the same decision. ${ }^{106}$

In a concurring opinion, Justice O'Connor wrote separately to emphasize a few points not addressed by the majority's opinion. One of these points was that the problem confronted by the Court could be avoided in the future based upon advance directives. ${ }^{107}$ Specifically, she noted that decisions such as the one before the Court "might be avoided if the State considered an equally probative source of evidence: the

99. $\quad I d$. at $* 2$.

100. 497 U.S. 261 (1990).

101. Id. at 265 .

102. Id.

103. Id.

104. Id. at 277 .

105. Id. at 278 .

106. Id. at 281-82.

107. Id. at 289-90 (O'Connor, J., concurring). 
patient's appointment of a proxy to make health care decisions on her behalf." 108 She also presciently pointed out that "[d]elegating the authority to make medical decisions to a family member or friend is becoming a common method of planning for the future." 109

Justice O'Connor observed that some states had started to allow agents appointed via durable power of attorney to make health care decisions while others "allow an individual to designate a proxy to carry out the intent of a living will." 110 Assessing these developments, Justice O'Connor concluded that " $[t]$ hese procedures for surrogate decisionmaking, which appear to be rapidly gaining in acceptance, may be a valuable additional safeguard of the patient's interest in directing his medical care." 111

\section{B. The Patient Self-Determination Act}

\section{INTRODUCTION}

In large part based upon the Supreme Court's decision in Cruzan, Congress passed the bipartisan Patient Self-Determination $\mathrm{Act}^{112}$ ("PSDA") in November 1990. ${ }^{113}$ Under the PSDA, any health care providers receiving Medicare or Medicaid payments must provide written information to patients regarding their rights under the law of the state in which the facility is located. ${ }^{114}$ This disclosure must include written information about the right "to make decisions concerning such medical care, including the right to accept or refuse medical or surgical treatment and the right to formulate advance directives." ${ }^{115}$ It also must include written information about "the written policies of the provider or organization respecting the implementation of such rights."

Importantly, this written information must be provided:

(A) in the case of a hospital, at the time of the individual's admission as an inpatient,

108. Id. at 290 (O'Connor, J., concurring).

109. Id. (O’Connor, J., concurring).

110. Id. at 290-91 (O'Connor, J., concurring).

111. Id. at 291-92 (O'Connor, J., concurring).

112. Omnibus Budget Reconciliation Act of $1990 \S \S 4206,4751,42$ U.S.C. $\S \S 1395 \mathrm{cc}(\mathrm{a})(1)(\mathrm{Q}),(\mathrm{f}), 1395 \mathrm{~mm}(\mathrm{c})(8), 1396 \mathrm{a}(\mathrm{a})(57),(58), 1396 \mathrm{a}(\mathrm{w})(2012)$.

113. Justin Waddell, Dead Letters: Protecting the Intentions of a Living Will Declarant with a Dedicated Advocate, 25 Geo. J. LeGAL Ethics 801, 806 (2012).

114. Richard E. Shugrue, The Patient Self-Determination Act, 26 CreIGHTON L. REV. 751, 761-62 (1993).

115. $\S 1395 \mathrm{cc}(\mathrm{f})(1)(\mathrm{A})(\mathrm{i})$.

116. $\S 1395 \mathrm{cc}(\mathrm{f})(1)(\mathrm{A})(\mathrm{ii})$. 
(B) in the case of a skilled nursing facility, at the time of the individual's admission as a resident,

(C) in the case of a home health agency, in advance of the individual coming under the care of the agency, [and]

(D) in the case of a hospice program, at the time of initial receipt of hospice care by the individual from the program .... ${ }^{117}$

After receiving this information, the patient can choose whether to execute an advance directive, which the PSDA defines as "a written instruction, such as a living will or durable power of attorney for health care, recognized under State law (whether statutory or as recognized by the courts of the State) and relating to the provision of such care when the individual is incapacitated." 118 The PSDA requires the health care facility "to document in a prominent part of the individual's current medical record whether or not the individual has executed an advance directive." 119

\section{GOALS OF THE PSDA}

\section{a. Pre-asserting rights before isolation}

Part of the reason for the passage of the PSDA was the recognition of the isolation that patients often face when admitted to health care facilities. ${ }^{120}$ This isolation is especially acute in cases where patients are faced with terminal illnesses and end-of-life decisions. ${ }^{121}$ Indeed, some have asserted that, "like soldiers and prisoners, they are . . . 'captives' of their disease, their physicians and hospital, and their enforced isolation." ${ }^{122}$ Moreover, elderly patients are often "frail, seriously sick, and socially isolated from the outset of the provider/patient relationship." ${ }^{123}$ In such cases:

117. $§ 1395 \mathrm{cc}(\mathrm{f})(2)$.

118. $§ 1395 \mathrm{cc}(\mathrm{f})(3)$.

119. $\S 1395 \mathrm{cc}(\mathrm{f})(1)(\mathrm{B})$.

120. See Lawrence P. Ulrich, The Patient Self-Determination Act: Meeting the Challenges in Patient Care 104-05 (1999). See generally Elizabeth McCloskey, Between Isolation and Intrusion: The Patient Self-Determination Act, 19 L. Med. \& Health Care 80 (1991).

121. D. Christian Addicott, Regulating Research on the Terminally Ill: $A$ Proposal for Heightened Safeguards, 15 J. Contemp. HeAlth L. \& PoL'y 479, 492 (1999).

122. Jay KATZ, EXPERIMENTATION With Human Beings 1053 (1972).

123. Marshall B. Kapp, Malpractice Liability in Long-Term Care: A Changing Environment, 24 CREIGHTON L. REV. 1235, 1238 (1991). 
The patient may understandably see herself as a burden-as requiring the family to waste the resources to maintain her in a painful and virtually incommunicado condition-until the money, the pain, and the technology is cut off by someone who neither knows her, nor really cares for her, but cares only that the medicare check comes in payment. ${ }^{124}$

By allowing a patient to pre-assert his health care rights, the PSDA empowers the patient to make important decisions "when the patient is healthy and before she "experiences the dislocation that often attends inpatient admission.'" 125 At the same time, the PSDA does not seek to coerce a patient into making certain health care decisions. During the Senate debate on the PSDA, an American Bar Association spokesperson expressed concern "for the indigent, poorly educated and isolated individuals who could be vulnerable to facile execution of documents urged upon them by over-enthusiastic caretakers." ${ }^{126}$ In response, the PSDA was written so that health care providers merely provide patients with information about advance directives, not the directives themselves. ${ }^{127}$

\section{b. Overcoming the secrecy of the physician-patient relationship}

The physician-patient relationship is traditionally shrouded in secrecy based upon a nexus of laws ensuring confidentiality. ${ }^{128}$ Collectively, these laws "shield doctor-patient interactions from the scrutiny of the outside world, thereby ensuring that the doctor's influence will go unmitigated and undetected." 129 Indeed, in the end-of-life context, "several commentators have concluded that the

124. Paul J. Zwier, Looking for a Nonlegal Process: Physician-Assisted Suicide and the Care Perspective, 30 U. RICH. L. REV. 199, 223 (1996).

125. Thaddeus Mason Pope, The Maladaption of Miranda to Advance Directives: A Critique of the Implementation of the Patient Self-Determination Act, 9 Health Matrix 139, 153 (1999) (quoting Susan M. Wolf et al., Sources of Concern About the Patient Self-Determination Act, 325 New ENG. J. MED. 1666, 1667 (1991)).

126. Living Wills: Hearing Before the Subcomm. on Medicare and Long-term Care of the S. Comm. on Fin., 101st Cong. 42 (1990) (statement of Charles P. Sabatino, Assistant Director, Commission on Legal Problems of the Elderly, American Bar Association).

127. See Edward J. Larson \& Thomas A. Eaton, The Limits of Advanced Directives: A History and Assessment of the Patient Self-Determination Act, 32 WAKE FOREST L. REV. 249, 265 (1997).

128. Patrick M. Curran, Jr., Note, Regulating Death: Oregon's Death with Dignity Act and the Legalization of Physician-Assisted Suicide, 86 GEO. L.J. 725, 740 (1998).

129. Id. at $740-41$. 
privacy of this relationship renders effective regulation of [physician-assisted suicide] impossible." 130

The PSDA addresses this issue in two meaningful ways. First, it ensures that, if end-of-life "disputes arise ... patients or their decision-makers and physicians will have a summary of patients' rights under state law to make life-sustaining medical treatment decisions." 131 Second, it facilitates the execution of advance directives, ensuring that there will be a written record of their wishes that will be known and honored by health care providers. ${ }^{132}$

\section{c. Counteracting the unfamiliarity of health care facilities}

The PSDA recognizes that patients being admitted into health care facilities can become disoriented based upon the unfamiliarity of the new staff and surroundings confronting them. ${ }^{133}$ The unfamiliar surroundings facing a patient upon admission make a health care facility a difficult place for patients to decide to execute advance directives. ${ }^{134}$ The PSDA, however, facilitates the execution of advance directives "when the patient is healthy and before she 'experiences the dislocation that often attends inpatient admission." "135

\section{d. Preventing coercion}

The PSDA was passed in large part to address the coercion that a patient can face when receiving medical care, especially in cases

130. Id. at 741; see also Daniel Callahan \& Margot White, The Legalization of Physician-Assisted Suicide: Creating a Regulatory Potemkin Village, 30 U. RICH. L. REV. 1, 8 (1996) ("If it is true, as it indubitably is, that "decisions about medical treatment are normally made in the privacy of the doctor-patient relationship,' then an obvious question must be asked: how is it possible, or could it ever be possible, to monitor and regulate those decisions regarding PAS that occur within the ambit of that privacy?" (footnotes omitted) (quoting Franklin G. Miller et al., Regulating Physician-Assisted Death, 331 New Eng. J. Med. 119, 119 (1994))).

131. Robert Gatter, Unnecessary Adversaries at the End of Life: Mediating End-of-Life Treatment Disputes to Prevent Erosion of Physician-Patient Relationships, 79 B.U. L. REV. 1091, 1126 (1999).

132. Charles P. Sabatino, National Advance Directives: One Attempt to Scale the Barriers, 1 NAELA J. 131, 135 (2005).

133. Marni J. Lerner, Note, State Natural Death Acts: Illusory Protection of Individuals' Life-Sustaining Treatment Decisions, 29 HARV. J. ON LEGIS. 175, 210 n. 180 (1992).

134. Tara Rayne Shewchuk, Completing Advance Directives for Health Care Decisions: Getting to Yes, 4 Psychol. PUB. POL'y \& L. 703, 713-14 (1998). at 1667$)$.

135. Pope, supra note 125, at 153 (quoting Wolf et al., supra note 125, 
involving possible end-of-life care. ${ }^{136}$ Many have argued that the physician-patient relationship is "inherently coercive" because "the balance of power between doctor and patient is almost entirely one-sided." ${ }^{137}$ Others have noted that the physician-patient relationship is rife with actual coercion because "physicians manipulate the consent process to obtain the result they desire by the tone and sequence in which they convey the risk information...."138 Moreover, the Supreme Court itself has recognized that end-of-life situations are especially rife with the risk of coercion. ${ }^{139}$ Finally, coercion is a concern throughout the field of advance directives and not limited to fear of doctor or hospital staff coercion. Some mental health advocates fear that family members may coerce persons with mental illness into signing advance directives, consenting to treatment they do not want. On the other hand, mental health professionals fear that advocates will persuade the mentally ill to reject both needed and wanted prospective treatment. $^{140}$

The PSDA addresses these concerns by informing patients about their health care rights so that they can choose whether to execute documents like advance directives before their condition deteriorates and they are more susceptible to heightened pressures from a variety of sources. ${ }^{141}$

\section{e. Promoting autonomy}

The PSDA was primarily passed because of the belief that patients were unable to exercise autonomy in making health care decisions under the existing framework. ${ }^{142}$ Specifically, most patients "cannot exercise even a semblance of autonomy about where they will spend

136. See Larson \& Eaton, supra note 127, at 267 (noting how one of the goals of the PSDA was to empower patients and alleviate concerns about coercion).

137. Curran, supra note 128 , at 740 .

138. Mark A. Hall, Theory of Economic Informed Consent, 31 GA. L. REV. 511, 570 n.178 (1997).

139. Washington v. Glucksburg, 521 U.S. 702, 732 (1997) (construing Cruzan v. Dir., Mo. Dep't of Health, 497 U.S. 261, 281 (1990)).

140. Justine A. Dunlap, Mental Health Advance Directives: Having One's Say?, 89 KY. L.J. 327, 374-75 (2000).

141. See Larson \& Eaton, supra note 127, at 265; Ben Kusmin, Note, Swing Low, Sweet Chariot: Abandoning the Disinterested Witness Requirement for Advance Directives, 32 Am. J.L. \& MED. 93, 99 (2006); Ruth F. Maron, Note, Who Has a Will to Live?: Why State Requirements for Advance Directives Should be Uniform(ly Revised), 24 Regent U. L. Rev. 169, 193 (2011); Lester J. Perling, Comment, Health Care Advance Directives: Implications for Florida Mental Health Patients, $48 \mathrm{U}$. MiAmi L. ReV. 193, 226-27 (1993).

142. See, e.g., John F. Peppin, Physician Neutrality and Patient Autonomy in Advance Directive Decisions, 11 IssuEs L. \& MED. 13, 15 (1995). 
their final days because such decisions are often fraught with coercion and fiscal pressures." 143 Indeed, patient autonomy was the primary principle guiding the creation of the PSDA. ${ }^{144}$

The PSDA was passed based on the recognition that informing patients of their health care rights after they have been admitted is often too late to allow them to effectively understand and assert those rights. ${ }^{145}$ By providing information at an earlier stage, the PSDA allows patients to engage in advance planning that "avoids the need for state coercion and incompetency adjudication with its accompanying labeling effects while preserving the individual's sense of dignity and autonomy." 146

The PSDA is directed more toward "the process of decisionmaking rather than the decision itself." 147 The intent behind the PSDA was "to give patients accurate and uniform information without creating undue anxiety or pressuring them to execute documents they either did not understand or genuinely want." 148 Because it requires health care providers to supply information concerning health care rights at an early stage, it ensures that patients are "allowed to make their own decisions about the use or nonuse of advance directives." 149

\section{MEDICAL MIRANDA}

The PSDA has frequently been described as "medical Miranda." 150 Indeed, co-sponsor John C. Danforth introduced the PSDA as an act

143. Arthur L. Caplan, Commentary: Can the Case Manager Offer Placement in Good Conscience?, in Ethical Conflict in the Management of Home Care: The Case Manager's Dilemma 133, 136 (Rosalie A. Kane \& Arthur L. Caplan eds., 1993); see also Pope, supra note 125, at 158.

144. See Larson \& Eaton, supra note 127, at 257; William M. Sage, Regulating Through Information: Disclosure Laws and American Health Care, 99 Colum. L. REV. 1701, 1705 n.9 (1999) ("For example, autonomy concerns led to the passage of the Patient Self-Determination Act (PSDA) . . . .").

145. See Larson \& Eaton, supra note 127, at 264 (quoting an American Hospital Association representative who stated during the debate on the PSDA that "[a]s a practical matter in many cases when the patient arrives at the hospital it is too late really to effectively deal with the situation").

146. Bruce J. Winick, The Side Effects of Incompetency Labeling and the Implications for Mental Health Law, 1 PsychOL. PUB. POL'y \& L. 6, 39 (1995).

147. Paul F. Stavis, The Nexum: A Modest Proposal for Self-Guardianship by Contract: A System of Advance Directives and Surrogate Committees-at-Large for the Intermittently Mentally Ill, 16 J. CONTEMP. HeAlTH L. \& POL'Y 1, 53 (1999) (quoting Larson \& Eaton, supra note 127, at 267).

148. Larson \& Eaton, supra note 127, at 267.

149. Id.

150. Pope, supra note 125, at 142; see also Fred H. Cate, Implementing the Education Mandate of the Patient Self-Determination Act, 7 Health Law., Fall 1993, 
that would create "health care's own Miranda warning." 151 The analogy makes sense because it requires medical providers to inform patients of their health care rights just like criminal Miranda obligates police officers to advise suspects of their right to counsel and their right to remain silent. ${ }^{152}$

\section{MIRANDA REVISITED}

\section{A. Introduction}

In its dicta in McNeil, the Supreme Court expressed skepticism about extending the Edwards prophylaxis to cover pre-assertions of Miranda rights for two primary reasons. First, the Court noted that most rights cannot be asserted until "the government seeks to take the action they protect against." 153 Second, the Court feared that it could place no meaningful limitations on the pre-assertion of the Miranda right to counsel if it approved such pre-assertion. ${ }^{154}$ Instead, the Miranda right to counsel could be asserted "by a letter prior to arrest" or "prior to identification as a suspect," with the police subsequently unable to interrogate the suspect in perpetuity. ${ }^{155}$

This section addresses this dicta and makes four arguments in favor of extending the Edwards prophylaxis to cover pre-assertions of Miranda rights. Part B of this section argues that the same principles

at 11,13 ("How do we keep the Act from becoming what has already been called a 'medical Miranda,' whose very familiarity causes patients to ignore its meaning and importance?"); Paul Cotton, Providers to Advise of 'Medical Miranda,' 265 JAMA 306 (1991); Michael A. Refolo, The Patient Self-Determination Act of 1990: Health Care's Own Miranda, 8 J. Contemp. Health L. \& Pol'y 455 (1992); Lerner, supra note 133, at 179 (noting that the PSDA is "[r]eferred to as a "medical Miranda warning"”); Doug Podolsky, A Right to Die Reminder: A New Law Requires Hospitals to Read You Your Medical Rights, U.S. News \& WorLd REP., Dec. 2, 1991, at 74 (noting that health care facilities must provide patients with a written "medical Miranda" outlining their health care rights); Leonard Sloane, '91 Law Says Failing Patients Must be Told of Their Options, N.Y. Times, Dec. 8, 1990, at A4.

151. See Pope, supra note 125, at 142 n.11 (noting that "Senator John C. Danforth of Missouri introduced the bill this way").

152. John D. Gorby, Viewing the "Draft Guidelines for State Court Decision Making in Authorizing or Withdrawing Life-Sustaining Medical Treatment" from the Perspective of Related Areas of Law and Economics: A Critique, 7 Issues L. \& MED. 477, 508 (1992) ("It has been described as a health care 'Miranda warning' because it informs patients about their basic rights to refuse treatment."); Sloane, supra note 150.

153. McNeil v. Wisconsin, 501 U.S. 171, 182 n.3 (1991).

154. Id.

155. Such a concern would not be present with pre-assertion of the right to remain silent because that right merely needs to be "scrupulously honored," allowing for officers to seek to interrogate the suspect hours later. See supra notes 37-39 and accompanying text. 
supporting the pre-assertion of health care rights that led to the passage of the PSDA justify legal recognition of the pre-assertion of Miranda rights. Part $\mathrm{C}$ of this section contends that courts have already laid the framework for pre-assertion of Miranda rights in a way that allows for equitable and meaningful limitations to be placed on pre-assertion. Part $\mathrm{D}$ of this section asserts that the Supreme Court's recent opinion in Maryland v. Shatzer ${ }^{156}$ quells concerns that authorizing pre-assertions would hinder police investigations in perpetuity. Finally, Part E of this section notes that the Supreme Court has recently created an important limitation on the principles at the heart of the Edwards prophylaxis that supports its extension to certain pre-assertions of Miranda rights.

\section{B. The Similar Justifications for Criminal and Medical Miranda}

\section{ASSERTING RIGHTS BEFORE ISOLATION}

The Miranda opinion was based to a large extent on the fact that most custodial interrogations take place "in the isolated setting of the police station," with the suspect being incommunicado, i.e., unable to communicate with others besides his interrogators. ${ }^{157}$ The Miranda Court began by noting that each of the cases before it involved "incommunicado interrogations of individuals in a police-dominated atmosphere ...."158 The Court observed that the largely incommunicado nature of most custodial interrogations keeps "what transpires at such interrogations" largely under wraps and also cited to a myriad of cases in which it previously uncovered police extortion of confessions via physical violence and "sustained and protracted questioning incommunicado . . .." 159

Later, the Court focused on three prior cases in which it reversed convictions because police engaged in mental rather than physical coercion during custodial interrogation. ${ }^{160}$ With regard to these interrogations, the Court concluded that, "[i]n other settings, these individuals might have exercised their constitutional rights. In the incommunicado police-dominated atmosphere, they succumbed." ${ }^{161}$ The Court later found a suspect's inability to speak with others (or his lack of knowledge of that ability) inconsistent with the privilege against

156. 559 U.S. 98 (2010).

157. Miranda v. Arizona, 384 U.S. 436, 461 (1966).

158. Id. at 445 .

159. Id. at 445-46.

160. Id. at 456 (citing Haynes v. Washington, 373 U.S. 503 (1963); Lynumn v. Illinois, 372 U.S. 528 (1963); Townsend v. Sain, 372 U.S. 293 (1963)).

161. Id. 
self-incrimination, noting that "[t]he current practice of incommunicado interrogation is at odds with one of our Nation's most cherished principles-that the individual may not be compelled to incriminate himself." 162

In terms of isolation, the Court pointed out that police manuals instruct officers " $\mathrm{t}] \mathrm{o}$ highlight the isolation and unfamiliar surroundings" of a stationhouse custodial interrogation. ${ }^{163}$ The Court thereafter determined that these practices are effective because, "[a]s a practical matter, the compulsion to speak in the isolated setting of the police station may well be greater than in courts or other official investigations, where there are often impartial observers to guard against intimidation or trickery." 164 Finally, the Court tied both the isolation and incommunicado strands of its analysis together, concluding that the government bears the heavy burden of proving subsequent waiver after a suspect who previously asserted his right to remain silent or right to an attorney subsequently waived that right. ${ }^{165}$ From the Court's perspective, "[s]ince the State is responsible for establishing the isolated circumstances under which the interrogation takes place and has the only means of making available corroborated evidence of warnings given during incommunicado interrogation, the burden is rightly on its shoulders." 166

In its subsequent opinion in United States $v$. Washington, ${ }^{167}$ the Court succinctly explained that "[a]ll Miranda's safeguards, which are designed to avoid the coercive atmosphere, rest on the overbearing compulsion which the Court thought was caused by isolation of a suspect in police custody." 168

\section{OVERCOMING THE SECRECY OF THE}

\section{POLICE OFFICER-SUSPECT RELATIONSHIP}

Because most suspects are incommunicado during isolated custodial interrogations at stationhouses, there is a privacy and secrecy that shrouds the process. The Miranda Court observed that "[i]nterrogation still takes place in privacy." ${ }^{169}$ According to the Court, this "[p]rivacy results in secrecy and this in turn results in a gap in our

\footnotetext{
162. Id. at $457-58$.

163. Id. at 450 .

164. Id. at 461 .

165. Id. at 475 .

166. Id.

167. 431 U.S. 181 (1977).

168. Id. at 187 n.5.

169. Miranda, 384 U.S. at 448.
} 
knowledge as to what in fact goes on in the interrogation rooms." 170 The Court again referenced police manuals, which inform officers "that the 'principal psychological factor contributing to a successful interrogation is privacy-being alone with the person under interrogation." "171 The privacy and secrecy of the process led the Court to conclude that preliminary advice by an attorney is insufficient; instead, upon request, counsel must be present throughout a custodial interrogation because "[e]ven preliminary advice given to the accused by his own attorney can be swiftly overcome by the secret interrogation process." 172

According to at least one source, "[t]he Miranda Court's greatest concern was the inherent coercion in incommunicado interrogation that arises from the privacy and secrecy of" custodial interrogations. ${ }^{173}$

\section{COUNTERACTING THE UNFAMILIARITY OF THE STATIONHOUSE}

While officers are required to give the Miranda warning whenever and wherever they subject suspects to custodial interrogation, the Miranda Court's opinion was born out of four cases in which police conducted interrogations within the four walls of the stationhouse. According to the Court, in each of the cases before it, "the defendant was thrust into an unfamiliar atmosphere and run through menacing police interrogation procedures." 174 As previously noted, the Miranda Court cited to police manuals, which instructed officers "[t]o highlight the isolation and unfamiliar surroundings" of a stationhouse custodial interrogation. ${ }^{175}$ The Court then went on to explain that

If at all practicable, the interrogation should take place in the investigator's office or at least in a room of his own choice. The subject should be deprived of every psychological advantage. In his own home he may be confident, indignant, or recalcitrant. He is more keenly aware of his rights and more reluctant to tell of his indiscretions of criminal behavior within the walls of his home. Moreover his family and other friends are nearby, their presence lending moral support. In his office, the investigator possesses all the advantages. The

170. Id.

171. Id. at 449 (quoting Fred E. Inbau \& John E. ReID, CRIMINAL INTERROGATION AND CONFESSIONS 1 (1962)).

172. Id. at 470 .

173. Lorraine J. Adler, New York's Loyalty to the Spirit of Miranda: Simply the Best for Twenty-Five Years, 47 VAND. L. REV. 889, 896 (1994).

174. Miranda, 384 U.S. at 457.

175. Id. at 450 . 
atmosphere suggests the invincibility of the forces of the law. ${ }^{176}$

As the Supreme Court later noted in Minnesota $v$. Murphy, ${ }^{177}$ "[m]any of the psychological ploys discussed in Miranda capitalize on the suspect's unfamiliarity with the officers and the environment." 178

\section{PREVENTING COERCION}

Given the aura of invincibility surrounding "the forces of the law," it is unsurprising that the Miranda Court deemed custodial interrogations inherently coercive. The Court deemed the Miranda warning necessary "to dispel the compulsion inherent in custodial surroundings ...." 179 Later, the Court found that custodial interrogation without the Miranda warning "contains inherently compelling pressures which work to undermine the individual's will to resist and to compel him to speak where he would not otherwise do so freely." 180 The Court then restated this conclusion even more forcefully, finding that the Miranda warning is "an absolute prerequisite in overcoming the inherent pressures of the interrogation atmosphere." ${ }^{181}$ The Miranda dissent put it the most concisely, characterizing the majority's position as declaring that "in-custody interrogation is inherently coercive," 182 a characterization that the Court has often repeated. ${ }^{183}$

The Court's conclusion in Miranda rested not merely on the coercion inherent in custodial interrogation but also on the actual coercive techniques that law enforcement officials are taught to apply while questioning suspects. As noted, some of these techniques involve isolating the suspect within the four walls of the stationhouse and making sure that the interrogation is conducted incommunicado. ${ }^{184}$ The Court also cited to police manuals instructing officers "to display an air

176. Id. at 449-50 (quoting ChARLES O'HARA, Fundamentals OF CRIMINAL INVESTIGATION 99 (1956)).

177. 465 U.S. 420 (1984).

178. Id. at 433 .

179. Miranda, 384 U.S. at 458.

180. Id. at 467 .

181. Id. at 468 .

182. Id. at 533 (White, J., dissenting).

183. See, e.g., United States v. Patane, 542 U.S. 630, 645 (2004) (Souter, J., dissenting) ("Miranda rested on insight into the inherently coercive character of custodial interrogation and the inherently difficult exercise of assessing the voluntariness of any confession resulting from it.").

184. See supra notes 163-66 and accompanying text. 
of confidence in the suspect's guilt and from outward appearance to maintain only an interest in confirming certain details." 185 Additionally, the Court referenced the recommendation that police officers team up to interrogate suspects, using the classic "good cop, bad cop" technique. ${ }^{186}$ The Court then later concluded:

From these representative samples of interrogation techniques, the setting prescribed by the manuals and observed in practice becomes clear. In essence, it is this: To be alone with the subject is essential to prevent distraction and to deprive him of any outside support. The aura of confidence in his guilt undermines his will to resist. He merely confirms the preconceived story the police seek to have him describe. Patience and persistence, at times relentless questioning, are employed. To obtain a confession, the interrogator must "patiently maneuver himself or his quarry into a position from which the desired objective may be attained." 187

\section{PROMOTING FREE CHOICE/AUTONOMY}

In the end, the Miranda Court combined all of the above factors to get to the heart of the issue: Law enforcement officers must not conduct custodial interrogations in a manner that runs afoul of the Fifth Amendment privilege against self-incrimination. ${ }^{188}$ And, according to the Court, a custodial interrogation only complies with the Fifth Amendment privilege if the interrogating officer apprises the suspect of his right to remain silent as well as his right to an attorney and secures a voluntary, knowing, and intelligent waiver of those rights. ${ }^{189}$

The purpose, then, of the Miranda warning is to ensure that the statements that a suspect makes in response to custodial interrogation are the result of a free and rational waiver of his constitutional rights. This is a theme that the Miranda majority repeated throughout its opinion. The Court found none of the four convictions under review to be constitutionally viable because "in none of these cases did the officers undertake to afford appropriate safeguards at the outset of the interrogation to insure that the statements were truly the product of free

185. Miranda, 384 U.S. at 450 (citing INBAU \& REID, supra note 171, at 34-43, 87).

186. See id. at 452 .

187. Id. at 455 (quoting Fred E. Inbau \& John E. Reid, Lie Detection AND CRIMINAL INTERROGATION 185 (3d ed. 1953)).

188. Id. at 444 .

189. Id. 
choice." ${ }^{190}$ This lack of appropriate safeguards meant that each defendant was put "in such an emotional state as to impair his capacity for rational judgment." 191

The Court then found that these concerns were not unique to the cases before it but instead would apply to any custodial interrogation: "Unless adequate protective devices are employed to dispel the compulsion inherent in custodial surroundings, no statement obtained from the defendant can truly be the product of his free choice." 192 Therefore, "whatever the background of the person interrogated, a warning at the time of the interrogation is indispensable to overcome its pressures and to insure that the individual knows he is free to exercise the privilege at that point in time." ${ }^{193}$ Moreover, a suspect must thereafter be able to invoke his right to remain silent and his right to an attorney "at any time prior to or during questioning" because, "[w]ithout the right to cut off questioning, the setting of in-custody interrogation operates on the individual to overcome free choice in producing a statement after the privilege has been once invoked." 194

As the Southern District of New York later explained in United States v. Dosanjh, ${ }^{195}$ Miranda requires "that the autonomy of the individual not be intimidated, or coerced, or compromised by ignorance." 196

\section{THE INEFFECTIVENESS OF MIRANDA}

Studies conducted over the course of more than four decades have consistently found that around eighty percent of adults waive their Miranda rights. ${ }^{197}$ Three decades of research also supports the empirical finding that more than ninety percent of juveniles waive their Miranda rights. ${ }^{198}$

Many have claimed that the Miranda warning is ineffective because it "come[s] too late to impose significant constraints on the

190. Id. at 457 .

191. Id. at 465 .

192. Id. at 458 .

193. Id. at 469 .

194. Id. at 474 .

195. No. 08 Cr. 211(AKH), 2008 WL 5209991 (S.D.N.Y. Dec. 11, 2008).

196. Id. at $* 5$.

197. Barry C. Feld, Real Interrogation: What Actually Happens when Cops Question Kids, 47 L. \& Soc'Y REV. 1, 11 (2013).

198. Id. 
acquisition of evidence from the accused." ${ }^{199}$ The Miranda warning is likely ineffective in large part because it primarily governs custodial interrogations conducted by detectives, "a small elite in the police force who can become trained and experienced in minimizing the effect of Miranda or even using it to their strategic advantage." 200 These detectives often "give[] considerable thought about how to use such warnings to their strategic advantage." 201 For instance, some detectives "preface[] the warnings with an explanation that they were part of the police's good-faith attempt to hear the suspect's side of the story before deciding whether to bring charges." ${ }^{202}$ As a result, when suspects realize they have said too much, "it [i]s almost always too late." 203

While many have dubbed the PSDA "medical Miranda," 204 the Act is actually much more efficacious than its criminal counterpart because it allows patients to assert their health care rights before admission. Conversely, criminal suspects cannot assert their Miranda rights until they are subjected to the very process that the Supreme Court has deemed inherently coercive. ${ }^{205}$

\section{PRE-ASSERTION OF RIGHTS BEFORE GOVERNMENTAL ACTION}

In McNeil, the Court noted that most rights cannot be asserted until "the government seeks to take the action they protect against." 206 To the extent that this statement is true, ${ }^{207}$ this thinking probably makes sense for most rights. For instance, why would a citizen need to assert his Eighth Amendment right against cruel and unusual punishment before the government seeks to sentence him to the death penalty, life imprisonment, or some other harsh criminal penalty? Similarly, why

199. Jacqueline Ross, Do Rules of Evidence Apply (Only) in the Courtroom? Deceptive Interrogation in the United States and Germany, 28 OXFORD J. LEGAL STUD. 443, 449 (2008).

200. Kent Roach \& M.L. Friedland, Borderline Justice: Policing in the Two Niagras, 23 AM. J. CRIM. L. 241, 295 (1996).

201. Id. at 294.

202. Id.

203. Id.

204. See supra notes $150-52$ and accompanying text.

205. See supra notes $182-83$ and accompanying text.

206. McNeil v. Wisconsin, 501 U.S. 171, 182 n.3 (1991).

207. It is unclear whether the McNeil Court's statement is in fact accurate. An argument could be made, for instance, that a citizen who files a petition for a parade or demonstration is pre-asserting his First Amendment rights before the government seeks to take contradictory action. Similarly, a party seeking a declaratory judgment determining whether a private contract might violate constitutional rights could be said to be pre-asserting his rights. See, e.g., BNSF Ry. Co. v. Tri-City \& Olympia R.R., No. CV-09-5062-EFS, 2011 WL 2607162, at*8-9 (E.D. Wash. July 1, 2011). 
would a citizen need to assert his Seventh Amendment right to a trial by jury before the government charges him with violating a criminal law? In either of these cases, it would be nonsensical for the citizen to pre-assert his rights, and no coercive force would prevent him from asserting his rights after the government sought to act.

Conversely, both health care and Miranda rights seem to fall into a different category based upon the unique circumstances surrounding their assertion. As previously noted, several sources have recognized the difficulty that both patients and suspects face in asserting their rights due to factors such as isolation and coercion. Therefore, it makes sense for both patients and suspects to be able to pre-assert their rights because the future versions of themselves might not be able to assert these rights. ${ }^{208}$

In similar contexts, legislatures have passed laws based upon exactly this type of thinking. One example of this type of law is a mandatory arrest law, which requires police officers responding to 911 calls to arrest suspects if they have probable cause to believe that they committed acts of domestic violence, regardless of whether the alleged victim consents to the arrest. ${ }^{209}$ Currently, approximately twenty-two states have some version of a mandatory arrest law, and many prosecutors' offices also have no-drop policies, which "require prosecution of a domestic violence perpetrator, regardless of the victim's wishes . . . ."210

The rationale for these laws and policies are the same as the rationale for the PSDA: when isolated with her abuser before his arrest and prosecution, a domestic violence victim might be coerced into not pressing charges or pursuing the case to trial. ${ }^{211}$ While many argue that

208. See Stephen J. Dubner, Save Me from Myself: A New Freakonomics Radio Podcast, FreaKonomics (Feb. 2, 2015, 9:24 AM), http://freakonomics.com/2012/02/ 02/save-me-from-myself-a-new-freakonomics-radio-podcast/.

209. See, e.g., Erin L. Han, Note, Mandatory Arrest and No-Drop Policies: Victim Empowerment in Domestic Violence Cases, 23 B.C. THIRD WorLd L.J. 159, 161 (2003).

210. Id.; see also Carolyn B. Ramsey, The Exit Myth: Family Law, Gender Roles, and Changing Attitudes Toward Female Victims of Domestic Violence, $20 \mathrm{MICH}$. J. GENDER \& L. 1, 9 (2013).

211. See, e.g., Aya Gruber, A "Neo-Feminist" Assessment of Rape and Domestic Violence Law Reform, 15 J. GENDER RACE \& JuST. 583, 601 (2012) ("The stock argument in support of mandatory arrest and prosecution is seductively logical: Because batterers coercively control abuse victims by allowing victims to decline arrest, allowing prosecution essentially cedes power over the criminal process to the batterer."); Allison J. Cambria, Note, Defying a Dead End: The Ramifications of Town of Castle Rock v. Gonzales on Domestic Violence Law and How the States Can Ensure Police Enforcement of Mandatory Arrest Statutes, 59 Rutgers L. REV. 155, 165 (2006). 
these laws and policies infringe upon the victim's autonomy, ${ }^{212}$ others claim that they promote the autonomy and empowerment of the victim by honoring the choice that she made to call 911 rather than her subsequent decision to drop the case after potentially being subjected to isolation and coercion. ${ }^{213}$

These same rationales similarly support the idea that the Edwards prophylaxis should be extended to allow suspects to pre-assert their Miranda rights. In Miranda, the Court found the Miranda warning to be constitutionally mandated to ensure that suspects either assert their rights or execute a voluntary, knowing, and intelligent waiver of those rights. ${ }^{214}$ But, as used to be the case with domestic violence victims as well as patients, especially those suffering from potentially terminal illnesses, there is a real danger that their ultimate decisions will be involuntary based upon a combination of factors such as isolation and coercion. ${ }^{215}$

\section{Applying the Existing Miranda Framework to Allow for Pre-Assertion}

\section{INVOCATION OF MIRANDA RIGHTS WHEN INTERROGATION IS “IMMINENT"}

Assuming that courts accept the general theory that the Edwards prophylaxis should be extended to cover some pre-assertions of Miranda rights, there is a remaining question over where to draw the

212. See, e.g., Dennis P. Saccuzzo, How Should the Police Respond to Domestic Violence: A Therapeutic Jurisprudence Analysis of Mandatory Arrest, 39 SANTA Clara L. REV. 765, 777 (1999) ("For example, critics have argued that mandatory arrest strips the battered person of her autonomy.").

213. See, e.g., Milton C. Regan, Jr., Marriage at the Millennium, 33 FAM. L.Q. 647, 656 (1999); Arthur L. Rizer III, Mandatory Arrest: Do We Need to Take a Closer Look?, 36 UWLA L. REV. 1, 13 (2005) ("In essence, he argues that mandatory arrest promotes the autonomy and empowerment of women.").

214. See supra note 25 and accompanying text.

215. Indeed, the argument for pre-assertion of medical and criminal Miranda rights is much stronger than the argument that mandatory arrest laws bolster victim autonomy. Mandatory arrest laws prevent a victim from changing her mind. An advance directive merely indicates a patient's wishes at the time of execution; nothing prevents the patient from amending or withdrawing such a directive if he changes his mind while of sound mind. See, e.g., Daryl L. Miller, Comment, Legal Killing: The Imminent Legalization of a Physician's Affirmative Aid-in-Dying, 34 SANTA Clara L. REV. 663, 708 (1994). Similarly, if a suspect were allowed to pre-assert his Miranda rights, nothing would prevent him from reinitiating communications with the police. Furthermore, if a suspect pre-asserted his Miranda right to counsel, nothing would prevent the police from interrogating him once counsel was appointed. See supra note 51 and accompanying text. 
line. In McNeil, the Court expressed concern that authorizing pre-assertion of the Miranda rights could lead to their assertion "by a letter prior to arrest" or "prior to identification as a suspect." 216 The possibility of such a slippery slope could be reason not to authorize pre-assertion because it could "unduly hamper[] the gathering of information." $" 217$

It appears, however, that a mechanism is already in place for courts to approve of a more incremental extension of the Edwards prophylaxis to cover only certain pre-assertions. As noted, courts across the country have used the McNeil dicta to conclude that Miranda rights cannot be invoked "in a context other than "custodial interrogation." "218 That said, both federal ${ }^{219}$ and state courts ${ }^{220}$ across the country have held that individuals can assert their Miranda rights either during custodial interrogation or "when an interrogation is imminent." 221 In other words, many courts have concluded that pre-assertion of the Miranda rights when interrogation is "imminent" is an assertion made in the context of custodial interrogation. ${ }^{222}$

Despite this language, however, courts have applied an extremely narrow construction to the word "imminent," which has only allowed suspects to invoke their Miranda rights "in response to or just before interrogation." ${ }^{223}$ For instance, in Hoerauf $v$. State, ${ }^{224}$ the defendant asked to speak to an attorney both while he was being fingerprinted during booking and while being placed in a holding cell hours before being taken to an interrogation room. ${ }^{225}$ Eventually, the defendant was taken to the interrogation room, waived his Miranda rights, and confessed. $^{226}$ In finding that the trial court properly denied the

216. McNeil v. Wisconsin, 501 U.S. 171, 182 n.3 (1991).

217. Davis v. United States, 512 U.S. 452, 461 (1994).

218. See supra notes 90-91 and accompanying text.

219. See, e.g., United States v. Bautista, 145 F.3d 1140, 1147 n.3 (10th Cir. 1998); United States v. LaGrone, 43 F.3d 332, 339 (7th Cir. 1994).

220. See, e.g., Sapp v. State, 690 So. 2d 581, 583 (Fla. 1997); People v. Villalobos, 737 N.E.2d 639, 645 (Ill. 2000).

221. Alston v. Redman, 34 F.3d 1237, 1249 (3d Cir. 1994).

222. See, e.g., United States v. Grimes, 142 F.3d 1342, 1348 (11th Cir. 1998) ("We find the reasoning of our fellow circuits persuasive and hold that Miranda rights may be invoked only during custodial interrogation or when interrogation is imminent.").

223. LaGrone, 43 F.3d at 340; see also State v. Appleby, 221 P.3d 525, 546 (Kan. 2009) ("Other courts have been very restrictive in defining 'imminent,' allowing no intervening activity between the invocation of the right and the planned initiation of questioning.").

224. Hoerauf v. State, 941 A.2d 1161 (Md. Ct. Spec. App. 2008).

225. Id. at 1167-68.

226. Id. at 1165-67. 
defendant's motion to suppress, the Court of Special Appeals of Maryland cited its prior opinion in Marr v. State, ${ }^{227}$ which in turn cited five federal courts in support of the proposition that Miranda rights can be asserted during actual or imminent custodial interrogation. ${ }^{228}$ The court, however, concluded that the defendant did not invoke his right to counsel when custodial interrogation was imminent; instead, "all such requests were made by appellant prior to being placed in the interrogation room and questioned by Detective Sofelkanik."229

Similarly, in Pardon v. State, ${ }^{230}$ Raymond Pardon asked to speak to an attorney after he was arrested and being booked into detention on the same charge that would lead to his custodial interrogation. ${ }^{231}$ The District Court of Appeal of Florida held that he had not validly invoked his right to counsel because the interrogation of Pardon was not imminent. ${ }^{232} \mathrm{He}$ was merely being booked into detention, albeit on the same charge on which he was later questioned. ${ }^{233}$ Questioning did not occur until a few hours later. ${ }^{234}$ Any request for an attorney at this point was an anticipatory invocation of his Miranda rights, which would not prevent the officers from later reading him his rights preparatory to interrogation. ${ }^{235}$

Indeed, in applying a limited construction to the word "imminent," the Third Circuit in Alston v. Redmond ${ }^{236}$ was only able to find two cases applying a somewhat broader construction of the word. ${ }^{237}$ Even these cases, however, did not apply expansive definitions of the word "imminent."

In United States $v$. Kelsey, ${ }^{238}$ Joseph Kelsey asked to see his attorney three or four times after being arrested in his home. ${ }^{239}$ The

227. Hoerauf, 941 A.2d at 1175 (citing Marr v. State, 759 A.2d 327 (Md. Ct. Spec. App. 2000)).

228. Marr, 759 A.2d at 339 (citing United States v. Grimes, 142 F.3d 1342, 1347-48 (11th Cir. 1998); LaGrone, 43 F.3d 332; United States v. Thompson, 35 F.3d 100 (2d Cir. 1994); Alston v. Redman, 34 F.3d 1237 (3d Cir. 1994); United States $v$. Wright, 962 F.2d 953 (9th Cir. 1992)).

229. Hoerauf, 941 A.2d at 1175.

230. 930 So. $2 d 700$ (Fla. Dist. Ct. App. 2006).

231. Id. at 703 .

232. Id. at 703-04.

233. Id. at 703 .

234. Id.

235. Id. at 703-04.

236. 34 F.3d 1237 (3d Cir. 1994).

237. Id. at 1248-49 ("We recognize that some courts, post-McNeil, have found a proper invocation of the Miranda right to counsel when a suspect has requested counsel prior to interrogation or to the reading of the Miranda rights.").

238. 951 F.2d 1196 (10th Cir. 1991).

239. Id. at 1198 . 
police, however, "did not question Kelsey at this point and did not read him his Miranda warnings until much later." ${ }^{240}$ Later, Kelsey was read the Miranda warning at his home, waived his Miranda rights, and confessed. ${ }^{241}$ The Tenth Circuit honored Kelsey's pre-assertion of his Miranda rights, concluding that Kelsey was in "precisely the type of coercive atmosphere that generates the need for application of the Edwards rule" when he was arrested in his home. ${ }^{242}$

In State v. Torres, ${ }^{243}$ the defendant was arrested for murdering her husband. ${ }^{244}$ She was subsequently detained in the conference room of the Sheriff's Department from 7:00 p.m. to 10:00 p.m., whereupon she was taken to the sheriff's office and told that she would be questioned shortly. ${ }^{245}$ The defendant asked to speak to counsel twice while in the conference room and once when taken to the sheriff's office. ${ }^{246}$ When she was eventually questioned at 10:35 p.m., however, she waived her Miranda rights and confessed. ${ }^{247}$ The Supreme Court of North Carolina found that the defendant had validly invoked her Miranda right because "[i]t would make little sense to require a defendant already in custody to wait until the onset of questioning or the recitation of her Miranda rights before being permitted to invoke her right to counsel." 248

While most courts have narrowly construed the term "imminent," at least one court has applied a more expansive construction. In State $v$. Hambly, ${ }^{249}$ Detectives Rindt and Clausing approached Scott Hambly "in a parking lot outside his apartment and attempted to convince him to speak to them without their taking him into custody." ${ }^{250}$ In response, Hambly repeatedly refused to speak, prompting Detective Rindt to place him under arrest. ${ }^{251}$ As Rindt shepherded Hambly to his squad car, Hambly "said that he wanted to speak to an attorney." 252 Rindt responded by placing Hambly "in the back of the car and told him that he could call an attorney once they arrived at the Washington County Jail." 253 Later, Hambly was read the Miranda warning, waived his

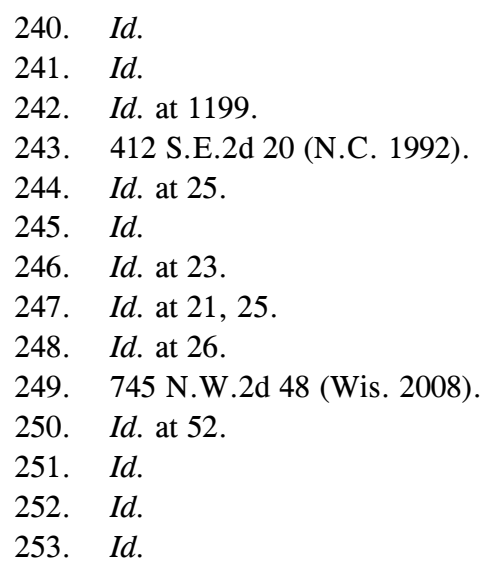


Miranda rights, and made a confession. ${ }^{254}$ The trial court eventually denied Hambly's motion to suppress his confession, and Hambly was ultimately convicted of delivery of cocaine. ${ }^{255}$

In addressing Hambly's subsequent appeal, the Supreme Court of Wisconsin concluded that a suspect can assert his Miranda rights when custodial interrogation is "imminent or impending." ${ }^{256}$ In finding that Hambly asserted his Miranda right to counsel when interrogation was imminent or impending, the court used the following reasoning:

In the minutes leading up to the defendant's request for counsel, Detective Rindt made it clear that he intended to question the defendant. The defendant could have reasonably surmised that because Rindt was persistent in wanting to interrogate him, Rindt would continue to attempt to interrogate him in a custodial setting after he refused to speak with Rindt in a noncustodial setting. The defendant had no reason to believe that Rindt's eagerness to question him dissipated once Rindt took him into custody. ${ }^{257}$

Hambly thus shows how most courts could easily apply the existing Miranda framework to allow for pre-assertions of Miranda rights by simply applying a broader definition of the word "imminent." That said, the court's opinion in Hambly was anything but easy. The court floated but rejected the possibility that a suspect should be able to assert his Miranda rights "any time the suspect is in custody, even before Miranda warnings or the onset of questioning." 258 The court also surveyed every case which had found that a suspect could invoke his Miranda rights when custodial interrogation was imminent but determined that none of these cases actually set forth a standard for defining imminence. ${ }^{259}$ Ultimately, the court concluded "that an interrogation is impending or imminent if a reasonable person in the defendant's position would have believed that interrogation was imminent or impending." 260

Hambly therefore illustrates another reason why courts could refuse to extend the Edwards prophylaxis to pre-assertions of Miranda rights. Currently, according to nearly all courts, suspects can only assert their Miranda rights during or just before custodial interrogation,

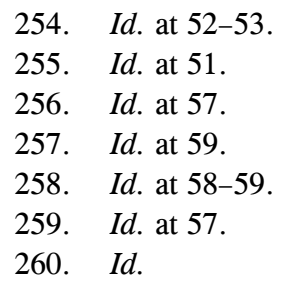


which is the same point in time when the police must administer the Miranda warning. The argument could thus be made that allowing suspects to pre-assert their Miranda rights would require courts to create a second test that is different from the test for determining when officers must administer the Miranda warning. Such an argument, however, would be misguided because courts can determine whether a suspect can pre-assert his Miranda rights by using the same test that they already apply for deciding whether an officer can pre-administer the Miranda warning.

\section{THE ABILITY OF OFFICERS TO PRE-ADMINISTER THE MIRANDA WARNING}

A year after the Supreme Court of Wisconsin decided Hambly, it handed down its decision in State v. Grady. ${ }^{261}$ In Grady, Marchand Grady voluntarily went to the police station to discuss the murder of Allen Jemison. ${ }^{262}$ Upon arrival at 8:16 p.m., Grady was indisputably not in custody when Detective Corbett began questioning him about the murder; nonetheless, "Detective Corbett began the interview by administering Miranda warnings to Grady so as to be 'better safe than sorry,' and Grady indicated that he understood the rights he was read." 263

At 10:45 p.m., another suspect being questioned separately said that Grady killed Jemison, resulting in Grady being placed under arrest. ${ }^{264}$ At this point, "Miranda warnings were not readministered to Grady," who made several inculpatory statements. ${ }^{265}$ Before trial, Grady moved to suppress his post-arrest statements, but the court denied his motion, and he was ultimately convicted of murder. ${ }^{266}$

On appeal, Grady asked the Supreme Court of Wisconsin to adopt a "bright-line rule," pursuant to which "any and all Miranda warnings prior to custody [are] ipso facto ineffective." 267 The court declined to adopt this bright-line rule and instead applied the totality of the circumstances test utilized by "the overwhelming majority of other courts who have considered this question." ${ }^{268}$ Under this test, courts determine whether the pre-administration of the Miranda warning

261. 766 N.W.2d 729 (Wis. 2009).

262. Id. at 731 .

263. Id.

264. Id. at 732 .

265. Id.

266. Id.

267. Id. at 733 .

268. Id. at 734 . 
before custody and the failure to re-administer the warning immediately before custodial interrogation is unconstitutional by looking at multiple factors,

including whether the same officer or officers conducted the questioning, whether the location changed, whether the subject matter of the questioning was consistent, whether a reminder of the Miranda rights was given before the custodial interrogation began, whether the suspect was mentally or emotionally impaired, whether more coercive tactics were used when the suspect was placed in custody, the suspect's past experience with law enforcement, and how much time elapsed between the administration of the Miranda warnings and the custodial interrogation or confession. ${ }^{269}$

In its opinion, the Grady court cited to a laundry list of opinions from courts around the country, each of which found that the pre-administration of the Miranda warning hours before custodial interrogation was constitutional, even when the warning was not re-administered immediately before custodial interrogation. ${ }^{270}$ The court then agreed with this analysis, noting that the goal of Miranda is "to inform the suspect that the interrogators will recognize his or her rights if exercised" and "ensure that a confession is free and unconstrained." 271 According to the court,

Given this purpose, a rule that assumes a suspect is a blank slate with no awareness of his or her rights as soon as he or she is placed in custody is a head-in-the-sand approach. In addition, application of Grady's bright-line rule would focus the analysis on the custody status of a suspect rather than on the individual's comprehension and waiver of his rights. It is, in short, form over substance. A rule that says warnings given one minute before custody are ineffective per se because they were not given when the suspect was actually in custody is manifestly unreasonable. ${ }^{272}$

In addition to finding that a bright-line rule against pre-administration betrayed Miranda's primary purpose, the court concluded that

269. Id. at 735-36.

270. Id. at 734 n.6.

271. Id. at 736 .

272. Id. 
beyond its lack of fidelity to the purposes and principles behind Miranda, Grady's approach is unworkable. One of its major flaws is that it assumes that the precise point of custody is fixed and known at the time of questioning. While this may sometimes be the case, it is not always true. In practice, it is not always clear when a suspect is officially under arrest. ${ }^{273}$

These lines of analysis by the court were eminently reasonable and similar to the analysis conducted by other courts on the issue. ${ }^{274}$ Conversely, this analysis lays bare the unreasonableness of courts failing to allow suspects to pre-assert their Miranda rights. If courts are unwilling to treat suspects like a blank slate at the start of custodial interrogation, why do they treat pre-assertions of Miranda rights as if they were written on Etch-a-Sketches simply because they were made before the technical definition of custodial interrogation? If the lack of clarity over when a suspect is technically in custody justifies allowing officers to pre-administer the Miranda warning, why are suspects, who have much less familiarity with the legal definition of custody, not similarly able to pre-assert their Miranda rights?

This Article thus proposes a test based on reciprocity and equanimity: Suspects should be allowed to pre-assert their Miranda rights under the same circumstances that officers are allowed to pre-administer the Miranda warning. In other words, if the totality of the circumstances supports a finding that an officer could pre-administer the Miranda warning, the same totality of the circumstances should support a finding that the suspect could pre-assert his Miranda rights.

For example, consider the outcomes in the following two cases: First, in People v. Petrone, ${ }^{275}$ Officer Roy Rodriguez responded to a 911 call regarding a robbery of money and jewelry at the house of Hazel Hudson. ${ }^{276}$ Later, about a mile and a half away from Hudson's house, Officer Rodriguez pulled over a car driven by John Petrone. ${ }^{277}$ Petrone consented to a search of his vehicle, which led to Officer Rodriguez discovering jewelry and $\$ 600$ in cash. ${ }^{278}$ Officer Rodriguez did not arrest Petrone but did read him the Miranda warning and asked him about the jewelry. ${ }^{279}$ Petrone responded that the jewelry belonged

273. Id.

274. Id.

275. No. F048289, 2006 WL 1321155 (Cal. Ct. App. May 16, 2006).

276. Id. at $* 1$.

277. Id.

278. Id. at $* 2$.

279. Id. 
to his mother and was in his car because he was in the process of moving and did not want it to get stolen. ${ }^{280}$

Officer Rodriguez then arrested Petrone and took him to the police station, where he subjected him to a custodial interrogation one hour and fifteen minutes later; Rodriguez never re-administered the Miranda warning. ${ }^{281}$ In finding no issue with the trial court's denial of Petrone's motion to suppress the statement he made during custodial interrogation, the appellate court applied the totality of the circumstances test. ${ }^{282}$ According to the court, "the effectiveness of appellant's initial waiver was not reduced by the one hour and fifteen minutes between when appellant was first Mirandized and when he was subsequently interrogated at the police station." 283

Second, in United States $v$. Stanley, ${ }^{284}$ Trooper Jay Poppe pulled over Leon Stanley for speeding. ${ }^{285}$ While conducting the traffic stop, Trooper Poppe noted some irregularities, such as the fact that Stanley's rental car had aftermarket tires and wheels. ${ }^{286}$ After being questioned about the nature of his trip, Stanley responded, "[T]his is all because of what happened in Missouri, isn't it?"287 When Trooper Poppe asked about Missouri, Stanley responded that he had been arrested with fourteen pounds of marijuana. ${ }^{288}$ Trooper Poppe asked for consent to search Stanley's vehicle, but Stanley refused to give consent. ${ }^{289}$

Trooper Poppe then told Stanley that he believed he was engaged in criminal activity and that he was detaining him pending the arrival of a narcotics-detection $\operatorname{dog} .{ }^{290}$ Stanley demanded to speak to an attorney on several occasions, but Trooper Poppe answered that Stanley did not have any right to counsel because he was merely being detained, not arrested. ${ }^{291}$ About half an hour later, the dog arrived and alerted to the trunk, leading to discovery of a gun but no drugs. ${ }^{292}$

At this point, Poppe placed Stanley under arrest and read him the Miranda warning. ${ }^{293}$ Stanley responded "that he had already requested,

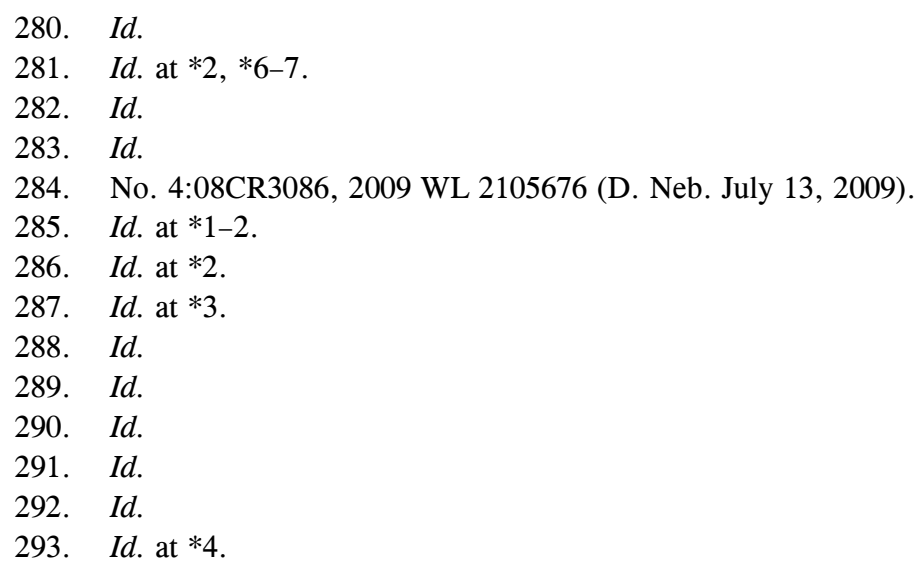


and been denied, a lawyer." 294 Trooper Poppe responded that "he was denied a lawyer while being detained, but now he is now under arrest." 295 Stanley waived his Miranda rights and later made incriminatory statements when interrogated in an interview room at traffic headquarters. ${ }^{296}$ The court later denied Stanley's motion to suppress his statements, citing McNeil's dicta about suspects not being able to invoke their Miranda rights anticipatorily in a context other than custodial interrogation. ${ }^{297}$

Given the factual similarity between Petrone and Stanley, it seems clear that the court would have had no problem with Trooper Poppe pre-administering the Miranda warning after calling for the narcotics-detection dog and failing to re-administer the Miranda warning before engaging in subsequent custodial interrogation. Therefore, the same dispensation should have been given to Stanley, allowing him to pre-assert his Miranda rights at the same point in time.

The same analysis could also be done in other contexts. For instance, courts have found that officers can pre-administer the Miranda warning while asking suspects for consent to search. ${ }^{298}$ Therefore, despite current precedent to the contrary, ${ }^{299}$ courts should find that suspects can pre-assert their Miranda rights when being asked to consent to searches. Because courts have allowed officers to pre-administer the Miranda warning before suspects take polygraph examinations, ${ }^{300}$ suspects should be able to pre-assert their Miranda rights at this same time, even if the Miranda warning is not given in connection with polygraph testing. ${ }^{301}$

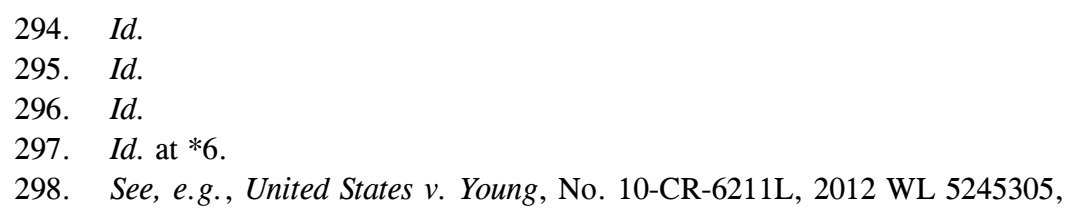
at *6 (W.D.N.Y. Oct. 19, 2012) ("In addition to advising him of his Miranda rights, the agents also informed Young that he did not have to consent to the search, and they explained and read the consent form to Young.").

299. See, e.g., United States v. LaGrone, 43 F.3d 332, 337 (7th Cir. 1994) ("LaGrone could not have invoked his Miranda right to counsel at the time he asked to call his attorney concerning the consent to search.").

300. See, e.g., State v. Rogers, No. M2002-01798-CCA-R3-DD, 2004 WL 1462649 , at $* 21$ (Tenn. Crim. App. June 30, 2004) ("[T]he defendant contends that because he was given no further Miranda warnings following the polygraph examination and change in status of the interrogation, his subsequent statements to the police should have been suppressed.").

301. Cf. State v. Nightingale, 58 A.3d 1057, 1064 (Me. 2012) ("Because the trial court did nor [sic] err in concluding that Nightingale was not in custody during the interrogation surrounding the polygraph, it follows that Shatzer's fourteen-day waiting period does not apply."). 
Such a reciprocal test is not merely rooted in fairness; it also means that courts would not have to create any new test for dealing with pre-assertions of Miranda rights, conserving judicial resources.

\section{The Limited Duration of Miranda Rights}

Prior to 2010, critics of expanding the Edwards prophylaxis to cover pre-assertions could claim that it would hinder police investigations because it would prevent officers from being able to interrogate suspects in perpetuity. First, such a criticism would not be entirely accurate because an officer could still interrogate such a suspect once he was given counsel or if the suspect himself reinitiated communications with the officer. ${ }^{302}$ Indeed, in the aforementioned Hambly case, in which the suspect pre-asserted his Miranda rights, the Supreme Court of Wisconsin found no constitutional violation because the suspect himself initiated further communications. ${ }^{303}$

Second, this criticism is no longer accurate at all after the Supreme Court's 2010 opinion in Maryland v. Shatzer. In Shatzer, Michael Shatzer was in prison for an unrelated crime when he was approached by a detective about allegations he had abused his son before being incarcerated. ${ }^{304}$ Thinking he was being questioned about the unrelated crime, Shatzer initially waived his Miranda rights but later refused to speak to the detective without an attorney upon realizing he was being asked about abusing his son. ${ }^{305}$ The detective immediately ceased questioning Shatzer. ${ }^{306}$ Two and a half years later, another detective approached Shatzer about the allegations he had abused his son. ${ }^{307}$ At this point, Shatzer waived his Miranda rights, failed a polygraph test, and eventually confessed to the crime. ${ }^{308}$

Shatzer later moved to suppress his confession, claiming that the Edwards prophylaxis precluded the detective from interrogating him once he had invoked his Miranda right to counsel. ${ }^{309}$ The trial court

302. See Edwards v. Arizona, 451 U.S. 477, 484-85 (1981) (finding that a suspect who has "expressed his desire to deal with the police only through counsel, is not subject to further interrogation by the authorities until counsel has been made available to him, unless the accused himself initiates further communication, exchanges, or conversations with the police").

303. State v. Hambly, 745 N.W.2d 48, 69-70 (Wis. 2008) ("For the reasons set forth, we conclude that the defendant 'initiated' further communication with Rindt.").

304. Maryland v. Shatzer, 559 U.S. 98, 100-01 (2010).

305. Id. at 101 .

306. Id.

307. Id.

308. Id. at 101-02.

309. Id. at 102 . 
denied Shatzer's motion to suppress, and the Supreme Court eventually agreed with this decision. ${ }^{310}$ First, the Supreme Court held that a return to the general prison population was a break in "custody," at least for Miranda purposes. ${ }^{311}$ Second, the court held that a break in custody of at least fourteen days renders the Edwards prophylaxis inapplicable; in other words, if an officer approaches a suspect at least fourteen days after he has validly asserted his Miranda right to counsel, the suspect's statements are not presumed to be involuntary. ${ }^{312}$

\section{E. The Edwards Prophylaxis Should Be Extended to Cover Pre-Assertions}

Ultimately, courts deciding whether to expand the Edwards prophylaxis to cover certain pre-assertions of Miranda rights must determine whether the benefits of extension outweigh the costs. ${ }^{313}$ The primary benefit of the Edwards prophylaxis is that it acts to "'[p]reserv[e] the integrity of an accused's choice to communicate with police only through counsel' by 'prevent[ing] police from badgering [him] into waiving his previously asserted Miranda rights." 314 Its secondary benefit is "conserv[ing] judicial resources which would otherwise be expended in making difficult determinations of voluntariness." 315 Conversely, the costs of the Edwards prophylaxis are "the in-fact voluntary confessions it excludes from trial, and the voluntary confessions it deters law enforcement officers from even trying to obtain." 316 Simply put, courts must determine whether the number of coerced confessions an expanded Edwards prophylaxis would exclude justify the number of voluntary confessions the expanded prophylaxis would prevent. ${ }^{317}$

In Shatzer, the Court refused to extend the Edwards prophylaxis because it concluded that the interrogation at issue did not implicate the "concer[n] that motivated the Edwards line of cases"318: "that the

310. Id. at $102,112-14$.

311. Id. at $112-14$.

312. Id. at $110-12$.

313. Id. at 106.

314. Id. (alterations in original) (citations omitted) (quoting Patterson $v$. Illinois, 487 U.S. 285, 291 (1998); Michigan v. Harvey, 494 U.S. 334, 350 (1990)).

315. Id. (alteration in original) (quoting Minnick v. Mississippi, 498 U.S. 146, 151 (1990)).

316. Id. at 108 .

317. Id. at 106 .

318. Id. at 115 (alteration in original) (quoting id. at 120 (Stevens, J., concurring)). 
suspect will be coerced into saying yes." ${ }^{319}$ Instead, the Court concluded that "there is no reason to believe a suspect will view confession as 'the only way to end his interrogation' when, before the interrogation begins, he is told that he can avoid it by simply requesting that he not be interrogated without counsel present-an option that worked before." 320

Conversely, in cases in which suspects seek to pre-assert their Miranda rights, their attempts are rebuffed. Indeed, such suspects are often flatly told that they cannot assert their rights. ${ }^{321}$ Therefore, when they are later read the Miranda warning, there is a significant reason to believe that they will view confessions as the only way to end their interrogations.

In Davis $v$. United States, ${ }^{322}$ the Supreme Court found that a suspect's Miranda rights were not violated because the suspect failed to unequivocally assert them. ${ }^{323}$ That said, in their opinion concurring in the judgment, four Justices partially analogized the case before them to the pre-Miranda opinion in Escobedo v. Illinois, ${ }^{324}$ in which the Supreme Court deemed a confession involuntary in large part due to the fact that the suspect's preliminary request to speak to an attorney was denied. ${ }^{325}$ According to the concurring Justices in Davis, "[w]hen a suspect understands his (expressed) wishes to have been ignored . . . , he may well see further objection as futile and confession (true or not) as the only way to end his interrogation." 326

In McNeil, the Supreme Court did not deny that allowing suspects to pre-assert their Miranda rights would preserve the integrity of the accused's choice. Instead, it merely worried that extending the Edwards prophylaxis would not conserve judicial resources because it would be impossible to place meaningful limitations on the ability of suspects to pre-assert their Miranda rights. ${ }^{327}$

This Article, however, has set forth a test that allows courts to put meaningful limitations on both the front and back end of the process. On the back end, the Court's recent opinion in Shatzer means that officers can interrogate a suspect fourteen days after pre-assertion of the Miranda right to counsel and even earlier if the suspect re-initiates

319. Id. at 115 .

320. Id. (quoting id. at 122 (Stevens, J., concurring)).

321. See supra note 291 and accompanying text.

322. 512 U.S. 452 (1992).

323. Id. at 461-62.

324. Id. at 472-73 (Souter, J., concurring) (citing Escobedo v. Illinois, 378

U.S. 478 (1964)).

325. Escobedo, 378 U.S. at 485.

326. Davis, 512 U.S. at 472-73 (Souter, J., concurring).

327. See supra note 76 and accompanying text. 
communications or is appointed an attorney. ${ }^{328}$ Meanwhile, if a suspect pre-asserts his right to silence, officers must merely "scrupulously honor" that right. ${ }^{329}$

On the front end, courts can conserve judicial resources by determining whether suspects can pre-assert their Miranda rights by applying the same totality-of-the-circumstances test that they use for deciding whether officers can pre-administer the Miranda warning. ${ }^{330}$ Under this test, suspects can only pre-assert their Miranda rights when custodial interrogation is "imminent," 331 quelling the McNeil Court's concern about suspects being able to pre-assert their rights at any point in time.

Most importantly, the pre-assertion scenario is the opposite of the scenario the Court confronted in Shatzer. Usually, the Court is skeptical about a suspect's decision to speak with authorities after initially invoking his Miranda rights. ${ }^{332}$ In Shatzer, the Court was able to overcome this skepticism based on the belief that a suspect who successfully asserted his right to counsel would believe he could make the same choice if officers waited at least fourteen days before approaching him again. ${ }^{333}$

In the pre-assertion context, however, a suspect's initial attempt to assert his Miranda rights is (currently) rejected. Sometimes, this rejection consists of the officer saying that the suspect cannot invoke his Miranda rights; ${ }^{334}$ other times, this rejection consists of the suspect immediately being placed under arrest. ${ }^{335}$ Given these circumstances, there is little reason to believe that the suspect will think that he can avoid custodial interrogation by asserting his Miranda rights given that his prior attempt at assertion did not work.

There is also little reason to believe that a suspect's decision to waive his Miranda rights after pre-assertion is the result of anything other than the inherently coercive nature of custodial interrogation. In Shatzer, the Court found that officers could reapproach a suspect

328. See supra note 312 and accompanying text.

329. See supra note 37 and accompanying text.

330. See supra Part III.C.

331. See supra Part III.C.

332. See, e.g., Michigan v. Mosley, 423 U.S. 96, 110 n.2 (1975) (White, J., concurring) (" $[\mathrm{T}] \mathrm{he}$ accused having expressed his own view that he is not competent to deal with the authorities without legal advice, a later decision at the authorities' insistence to make a statement without counsel's presence may properly be viewed with skepticism.").

333. See supra note 320 and accompanying text.

334. See supra note 291 and accompanying text.

335. See supra note 9 and accompanying text. 
fourteen days after he initially asserted his Miranda right to counsel by using the following reasoning:

When ... a suspect has been released from his pretrial custody and has returned to his normal life for some time before the later attempted interrogation, there is little reason to think that his change of heart regarding interrogation without counsel has been coerced. He has no longer been isolated. He has likely been able to seek advice from an attorney, family members, and friends. And he knows from his earlier experience that he need only demand counsel to bring the interrogation to a halt. . . . His change of heart is less likely attributable to "badgering" than it is to the fact that further deliberation in familiar surroundings has caused him to believe (rightly or wrongly) that cooperating with the investigation is in his interest. Uncritical extension of Edwards to this situation would not significantly increase the number of genuinely coerced confessions excluded. The "justification for a conclusive presumption disappears when application of the presumption will not reach the correct result most of the time." 336

In pre-assertion cases covered by the test proposed in this Article, none of these factors are present. The "earlier experience" of suspects in these cases is unsuccessful assertion of Miranda rights, which might make them believe subsequent attempts at assertion would be futile. Given that suspects would only be allowed to pre-assert their Miranda rights when custodial interrogation is "imminent," these suspects are not able to return to their normal lives for any period of time. Therefore, there is no reason to believe that they had a change of heart regarding waiver and every reason to believe that their confessions are simply the product of a process that the Supreme Court has deemed "inherently coercive." 337 Accordingly, legal acknowledgment of pre-assertions of Miranda rights will likely lead to the correct result most of the time.

\section{CONCLUSION}

In its opinion in Miranda, the Supreme Court required officers to give what is now known as the Miranda warning so that suspects would

336. Maryland v. Shatzer, 559 U.S. 98, 107-08 (2010) (footnote omitted) (quoting Coleman v. Thompson, 501 U.S. 722,737 (1991)).

337. See supra note $182-83$ and accompanying text. 
have a "full opportunity" and a "continuous opportunity" to exercise their Fifth Amendment rights. ${ }^{338}$ Decades of empirical data, however, reveal that this opportunity is illusory, with around eighty percent of suspects waiving their Miranda rights. ${ }^{339}$ This Article has identified the likely reason for this under-assertion: the inability of suspects to pre-assert their Miranda rights until they are subjected to the very process that the Supreme Court has described as "inherently coercive." $" 340$

The unwillingness of courts to honor pre-assertions of Miranda rights can be traced back to dicta from the Supreme Court's opinion in McNeil. The McNeil Court cautioned against crediting pre-assertions because most rights cannot be anticipatorily asserted and because meaningful limitations could not be placed upon the right to pre-assert. This Article has identified the PSDA, the so-called "medical Miranda," as a useful analogue that demonstrates how allowing pre-assertion of certain rights can bolster autonomy and counteract the effects of coercion and isolation. Given the comparisons between the physician-patient and officer-suspect relationships, the same principles that support the pre-assertion of medical Miranda rights also support the pre-assertion of criminal Miranda rights. Moreover, the framework is already in place for courts to credit such pre-assertions in an equitable way that will not strain judicial resources.

338. Miranda v. Arizona, 384 U.S. 436, 467 (1966).

339. See supra note 197 and accompanying text.

340. See supra note $182-83$ and accompanying text. 